\title{
The Synthesis of a Bis(thiosemicarbazone) Macrocyclic Ligand and the Mn(II), Co(II), Zn(II) and ${ }^{68} \mathrm{Ga}$ (III) Complexes
}

\author{
Melyssa L. Grieve ${ }^{1}\left(\mathbb{D}\right.$, Patrick R. W. J. Davey $\left.{ }^{1} \mathbb{(}\right)$, Craig M. Forsyth ${ }^{1}$ and Brett M. Paterson ${ }^{1,2, *(\mathbb{C})}$ \\ 1 School of Chemistry, Monash University, Clayton, VIC 3800, Australia; \\ melyssa.grieve1@monash.edu (M.L.G.); patrick.davey1@monash.edu (P.R.W.J.D.); \\ craig.forsyth@monash.edu (C.M.F.) \\ 2 Monash Biomedical Imaging, Monash University, Clayton, VIC 3800, Australia \\ * Correspondence: brett.paterson@monash.edu
}

Citation: Grieve, M.L.; Davey,

P.R.W.J.; Forsyth, C.M.; Paterson, B.M. The Synthesis of a

Bis(thiosemicarbazone) Macrocyclic Ligand and the Mn(II), Co(II), Zn(II) and ${ }^{68} \mathrm{Ga}(\mathrm{III})$ Complexes. Molecules 2021, 26, 3646. https://doi.org/ $10.3390 /$ molecules 26123646

Academic Editor: Hiroyuki Takemura

Received: 21 May 2021

Accepted: 11 June 2021

Published: 15 June 2021

Publisher's Note: MDPI stays neutral with regard to jurisdictional claims in published maps and institutional affiliations.

Copyright: (c) 2021 by the authors. Licensee MDPI, Basel, Switzerland. This article is an open access article distributed under the terms and conditions of the Creative Commons Attribution (CC BY) license (https:/ / creativecommons.org/licenses/by/ $4.0 /)$.
Abstract: A 1,4,7,10-tetraazacyclododecane (cyclen) variant bearing two thiosemicarbazone pendant groups has been prepared. The ligand forms complexes with $\mathrm{Mn}^{2+}, \mathrm{Co}^{2+}$ and $\mathrm{Zn}^{2+}$. X-ray crystallography of the $\mathrm{Mn}^{2+}, \mathrm{Co}^{2+}$ and $\mathrm{Zn}^{2+}$ complexes showed that the ligand provides a six-coordinate environment for the metal ions. The $\mathrm{Mn}^{2+}$ and $\mathrm{Zn}^{2+}$ complexes exist in the solid state as racemic mixtures of the $\Delta(\delta, \delta, \delta, \delta) / \Lambda(\lambda, \lambda, \lambda, \lambda)$ and $\Delta(\lambda, \lambda, \lambda, \lambda) / \Lambda(\delta, \delta, \delta, \delta)$ diastereomers, and the $\mathrm{Co}^{2+}$ complex exists as the $\Delta(\delta, \delta, \delta, \delta) / \Lambda(\lambda, \lambda, \lambda, \lambda)$ and $\Delta(\lambda, \lambda, \lambda, \delta) / \Lambda(\delta, \delta, \delta, \lambda)$ diastereomers. Density functional theory calculations indicated that the relative energies of the diastereomers are within $10 \mathrm{~kJ} \mathrm{~mol}^{-1}$. Magnetic susceptibility of the complexes indicated that both the $\mathrm{Mn}^{2+}$ and $\mathrm{Co}^{2+}$ ions are high spin. The ligand was radiolabelled with gallium-68, in the interest of developing new positron emission tomography imaging agents, which produced a single species in high radiochemical purity $(>95 \%)$ at $90{ }^{\circ} \mathrm{C}$ for $10 \mathrm{~min}$.

Keywords: thiosemicarbazone; macrocycle; transition metal; cyclen; gallium-68; coordination chemistry; radiochemistry

\section{Introduction}

Thiosemicarbazone functional groups are versatile N,S donors that can coordinate metal ions as neutral or anionic ligands, with the resulting complexes displaying diverse coordination chemistry. In general, thiosemicarbazones are easy to synthesise by way of a condensation reaction between a thiosemicarbazide and an aldehyde or ketone. The structures can be modified in multiple ways, allowing for the generation of tri-, tetra-, pentaor even hexadentate ligands, as well as multinuclear complexes and coordination polymers [1-9]. Modifications to the thiosemicarbazone substituents can also result in dramatic changes to the structural, physical and biological properties of the metal complexes $[10,11]$.

Hybrid ligands containing thiosemicarbazone groups and additional donor atoms can introduce modifiable properties to the complexes for a variety of biological applications [12-14]. N-heterocyclic thiosemicarbazones have been investigated for their pharmacological properties, which have shown that the metal complexes can display bioactivities which differ from those of either the ligand or the metal ion [15-18]. Lipophilic $\mathrm{Mn}^{2+}, \mathrm{Zn}^{2+}$ and $\mathrm{Ga}^{3+}$ complexes have demonstrated anti-tumour activity due to their ability to facilitate intracellular delivery of the free ligand upon metal dissociation or transmetallation to the $\mathrm{Fe}^{3+}$ or $\mathrm{Cu}^{2+}$ complexes [19-24]. Cobalt thiosemicarbazonato complexes have been isolated in the $\mathrm{Co}^{2+}$ and $\mathrm{Co}^{3+}$ oxidation states and have been investigated as redox-active prodrugs for hypoxia targeting and as anti-bacterial and anti-cancer agents [25-27]. Zinc ions have been found to play an important role in medicine, with compounds developed for treating neurodegeneration as well as anti-diabetic, anti-tumour, anti-bacterial, anti-microbial and anti-inflammatory agents [16,28-34]. 
Radioactive metal complexes of bis(thiosemicarbazonato) ligands derived from 1,2diones have been of interest for diagnostic and therapeutic applications. The ligands form complexes with positron-emitting isotopes of copper such as copper-64 $\left({ }^{64} \mathrm{Cu}, \mathrm{t}_{1 / 2}=12.7 \mathrm{~h}\right)$ that have been investigated as perfusion and hypoxia imaging agents and as probes for measuring altered copper trafficking in the brain during Alzheimer's disease [35-38]. Copper complexes of thiosemicarbazone-pyridylhydrazone hybrid ligands, incorporating a targeting group within the chelate domain, demonstrate blood-brain barrier permeability and an ability to bind to amyloid- $\beta$ plaques in vitro, and have the potential to assist with Alzheimer's disease diagnosis [39,40]. Bis(thiosemicarbazones) have also gained attention as bifunctional chelators for labelling small peptides with radioactive isotopes of copper due to their fast radiolabelling kinetics under ambient conditions, and peptide coupling routes by way of ligands with pendant amine or carboxylic acid groups [41-43].

The positron emitter gallium- $68\left({ }^{68} \mathrm{Ga}, \mathrm{t}_{1 / 2}=68 \mathrm{~min}\right)$ is readily obtained from a ${ }^{68} \mathrm{Ge} /{ }^{68} \mathrm{Ga}$ generator from which it is eluted as a $\left[{ }^{68} \mathrm{Ga}\right]\left[\mathrm{GaCl}_{4}\right]^{-}$solution in aqueous acidic solution and is increasingly utilised for positron emission tomography (PET) [44]. The ${ }^{68} \mathrm{Ga}^{3+}$ ion, administered as the citrate and nitrate salts, has been used to image tumours, inflammation and infection [45]. Incorporating the radionuclide into a stable bifunctional chelator is a method that allows for effective targeting to a wide range of disease states such as prostate cancer and neuroendocrine tumours [46-48]. Interest in the development of chelating agents for ${ }^{68} \mathrm{Ga}^{3+}$ has been ongoing, mostly due to the requirements for fast radiolabelling in high yields at moderate temperatures and in vivo stability $[49,50]$.

Macrocyclic polyamines such as 1,4,7,10-tetraazacyclododecane (cyclen) have been utilised in materials chemistry, medicinal chemistry, bioinorganic chemistry and chemical biology [51-54]. The metal complexes of macrocyclic polyamines have been vital to the development of radiopharmaceuticals owing to the higher kinetic inertness and thermodynamic stability in comparison to metal complexes of acyclic ligands [55-58]. The modifiable structures and the versatile chemistry of macrocyclic polyamines make them attractive scaffolds for generating hybrid ligands. These ligands incorporate various functional groups in an effort to assemble metal complexes suitable for a multitude of applications. The chelator 1,4,7,10-tetraazacyclododecane-1,4,7,10-tetraacetic acid (DOTA) is widely utilised to produce $\mathrm{Gd}^{3+}$ and $\mathrm{Mn}^{2+}$ magnetic resonance contrast agents and ${ }^{68} \mathrm{Ga}^{3+},{ }^{64} \mathrm{Cu}^{2+}$ and ${ }^{177} \mathrm{Lu}^{3+}$ radiopharmaceuticals [58-62].

Previously, we have used the tetraazamacrocyclic framework of cyclen to integrate two pendant semicarbazone groups to produce an octadentate chelator for $\mathrm{Pb}^{2+}$ and $\mathrm{Bi}^{3+}$ radionuclides [63]. In this work, we investigated the coordination chemistry of a tetraazamacrocycle incorporating thiosemicarbazone pendant groups with the transition metals $\mathrm{Mn}^{2+}, \mathrm{Co}^{2+}$ and $\mathrm{Zn}^{2+}$. Thiosemicarbazone complexes of ${ }^{68} \mathrm{Ga}^{3+}$ and the gamma emitting radioisotope ${ }^{67} \mathrm{Ga}^{3+}$ have been prepared previously, which prompted an investigation of the ${ }^{68} \mathrm{Ga}^{3+}$ radiolabelling properties of the new chelator [64-67].

\section{Results and Discussion}

\subsection{Synthesis of $\mathrm{H}_{2} \mathbf{L}$ and the Manganese(II), Cobalt(II) and Zinc(II) Complexes}

The synthesis of the diketone $1,1^{\prime}$-(4,10-dimethyl-1,4,7,10-tetraazacyclododecane-1,7diyl)bis(propan-2-one) (1) has been previously reported [63]. The synthesis of $\mathrm{H}_{2} \mathbf{L}$ involves a condensation reaction between the ketone groups of 1 and two equivalents of 4-methyl-3thiosemicarbazide (Scheme 1). 
<smiles>CC(=O)CN1CCCN(C)CCN(C)CCN(C)CC1</smiles>

1

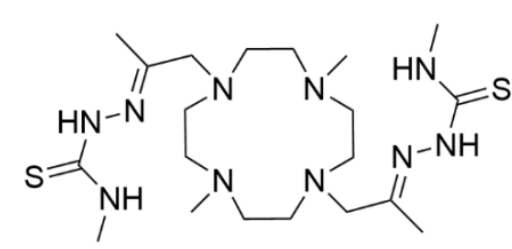

$\mathrm{H}_{2} \mathbf{L}$

Scheme 1. The synthetic route for the synthesis of $\mathrm{H}_{2}$ L. i) 4-methyl-3-thiosemicarbazide, acetic acid, ethanol, rt, $48 \mathrm{~h}$.

$\mathrm{H}_{2} \mathbf{L}$ was characterised by ${ }^{1} \mathrm{H}$ and $\left.{ }^{13} \mathrm{C}_{\{}{ }^{1} \mathrm{H}\right\}$ NMR spectroscopy. Variable-temperature ${ }^{1} \mathrm{H}$ NMR demonstrated sharpening of the macrocyclic $\mathrm{CH}_{2}$ proton signals $(\delta=2.70-2.85 \mathrm{ppm})$ as the temperature increased, which suggested fluxionality (Figure S3) [68]. High-resolution mass spectrometry analysis showed an isotopic pattern at $\mathrm{m} / z=487.31987$ corresponding to the $\left[\mathrm{H}_{2} \mathrm{~L}+\mathrm{H}\right]^{+}$cation (Figure S7). Analytical-HPLC indicated the presence of a single compound $\left(R_{\mathrm{T}}=5.27 \mathrm{~min}\right)$ (Figure $\left.\mathrm{S} 11\right)$.

The addition of the metal acetate salts to a suspension of $\mathrm{H}_{2} \mathbf{L}$ in methanolic solution gave the complexes $[\mathrm{MnHL}]^{+},[\mathrm{CoHL}]^{+}$and $[\mathrm{ZnHL}]^{+}$(Scheme 2). Addition of $\mathrm{NaBPh}_{4}$ resulted in precipitation of the complexes as the tetraphenylborate salts. Highresolution mass spectrometry analysis showed isotopic patterns at $\mathrm{m} / \mathrm{z}=540.2335,544.2298$ and 549.2249 attributed to the $[\mathrm{MnHL}]^{+},[\mathrm{CoHL}]^{+}$and $[\mathrm{ZnHL}]^{+}$complex cations, respectively (Figures S8-S10). Analytical-HPLC showed the presence of the compounds at retention times of $6.06,6.05$ and $6.01 \mathrm{~min}$ attributed to the $[\mathrm{MnHL}]\left(\mathrm{BPh}_{4}\right),[\mathrm{CoHL}]\left(\mathrm{BPh}_{4}\right)$ and $[\mathrm{ZnHL}]\left(\mathrm{BPh}_{4}\right)$ complexes, respectively (Figures S12-S14). Single crystals of the tetraphenylborate coordination compounds were obtained by slow diffusion of diethyl ether into solutions of the compounds in acetone.

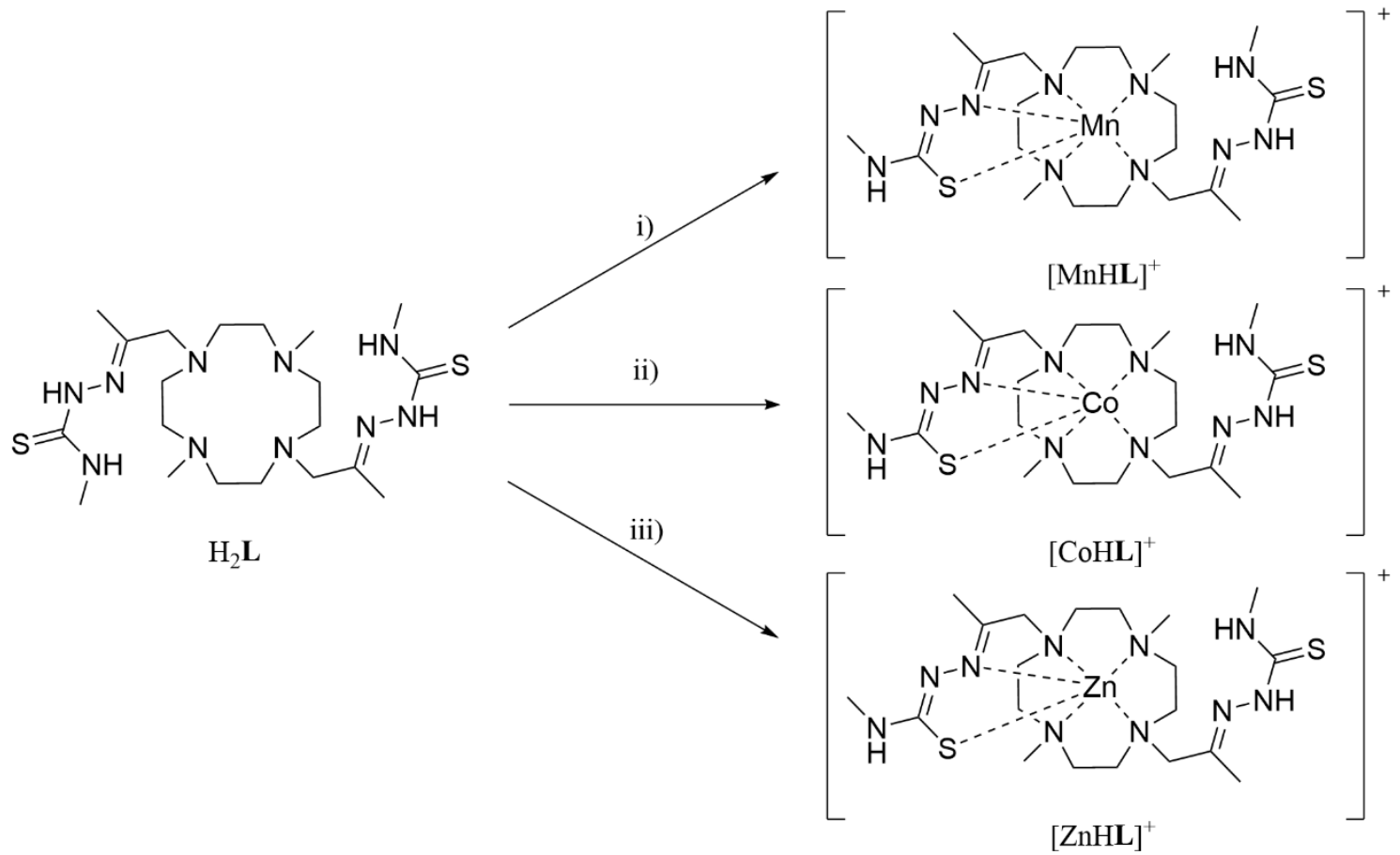

Scheme 2. Synthesis of $[\mathrm{MnHL}]\left(\mathrm{BPh}_{4}\right),[\mathrm{CoHL}]\left(\mathrm{BPh}_{4}\right)$ and $[\mathrm{ZnHL}]\left(\mathrm{BPh}_{4}\right)$. i) $\mathrm{Mn}(\mathrm{OAc})_{2} \cdot 4 \mathrm{H}_{2} \mathrm{O}, \mathrm{methanol}^{\mathrm{rt}}, \mathrm{NaBPh} 4,24 \mathrm{~h}$; ii) $\mathrm{Co}(\mathrm{OAc})_{2} \cdot 4 \mathrm{H}_{2} \mathrm{O}$, methanol, rt, $\mathrm{NaBPh}_{4}, 24 \mathrm{~h}$; iii) $\mathrm{Zn}(\mathrm{OAc})_{2} \cdot 2 \mathrm{H}_{2} \mathrm{O}$, methanol, rt, $\mathrm{NaBPh}_{4}, 24 \mathrm{~h}$. 


\subsection{NMR Studies}

The complex $[\mathrm{ZnHL}]\left(\mathrm{BPh}_{4}\right)$ was characterised by ${ }^{1} \mathrm{H}$ and ${ }^{13} \mathrm{C}\left\{{ }^{1} \mathrm{H}\right\}$ NMR spectroscopy. The presence of one equivalent of tetraphenylborate and a single hydrazinic nitrogen proton $(\delta=10.01 \mathrm{ppm})$ indicated deprotonation of the ligand at the hydrazinic nitrogen of the coordinated pendant arm. The ligand resonances in the ${ }^{1} \mathrm{H}$ NMR spectrum for the thiosemicarbazonato coordinated pendant arm of $[\mathrm{ZnHL}]\left(\mathrm{BPh}_{4}\right)$ have shifted compared to the spectrum for $\mathrm{H}_{2} \mathbf{L}$ and the non-coordinated arm (Figure 1). For example, the methyl group in the pendant arm at $\delta=1.96 \mathrm{ppm}$ in the ${ }^{1} \mathrm{H}$ NMR spectrum of $\mathrm{H}_{2} \mathbf{L}$ splits into two peaks at $\delta=1.96$ and $2.03 \mathrm{ppm}$ for the complex. The two methyl groups attached to the macrocycle shifted from $\delta=2.45 \mathrm{ppm}$ for $\mathrm{H}_{2} \mathbf{L}$ to $\delta=2.31 \mathrm{ppm}$ for $[\mathrm{ZnHL}]\left(\mathrm{BPh}_{4}\right)$. A significant shift was observed for the terminal $\mathrm{NH}$ proton of the thiosemicarbazonato arm from $\delta=8.22 \mathrm{ppm}$ to $6.56 \mathrm{ppm}$. Although the signals due to the protons of the macrocycle of $[\mathrm{ZnHL}]\left(\mathrm{BPh}_{4}\right)(\delta=2.40-3.04 \mathrm{ppm})$ are somewhat broad, variable-temperature analysis of the ${ }^{1} \mathrm{H}$ NMR spectra indicated that, unlike $\mathrm{H}_{2} \mathbf{L}$, this was not temperature dependent (Figure S6).

$\mathbf{a}$

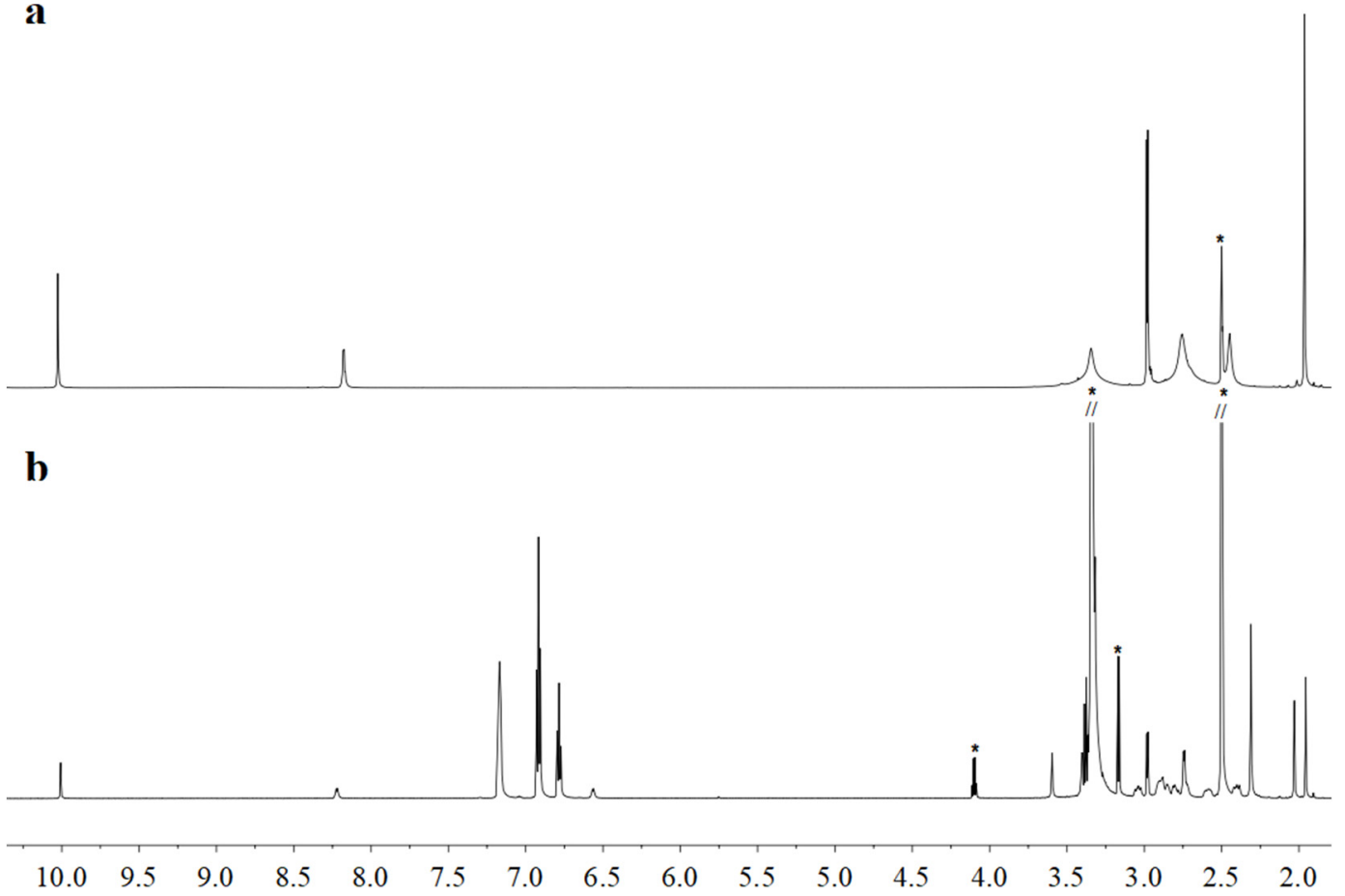

Figure 1. (a) The ${ }^{1} \mathrm{H}$ NMR spectrum of $\mathrm{H}_{2} \mathbf{L}$ in DMSO- $d_{6}$ at $25^{\circ} \mathrm{C}$. (b) The ${ }^{1} \mathrm{H}$ NMR spectrum of $[\mathrm{ZnHL}]\left(\mathrm{BPh}_{4}\right)$ in $\mathrm{DMSO}-d_{6}$ at $25^{\circ} \mathrm{C}$. Residual solvent peaks are marked with an asterisk.

\subsection{X-ray Crystal Structures of $[\mathrm{MnHL}]\left(\mathrm{BPh}_{4}\right),[\mathrm{CoHL}]\left(\mathrm{BPh}_{4}\right)$ and $[\mathrm{ZnHL}]\left(\mathrm{BPh}_{4}\right)$}

The coordination compounds $[\mathrm{MnHL}]\left(\mathrm{BPh}_{4}\right),[\mathrm{CoHL}]\left(\mathrm{BPh}_{4}\right) \cdot\left(\mathrm{C}_{3} \mathrm{H}_{6} \mathrm{O}\right)$ and $[\mathrm{ZnHL}]$ $\left(\mathrm{BPh}_{4}\right) \cdot 1.67\left(\mathrm{C}_{3} \mathrm{H}_{6} \mathrm{O}\right)$ crystallised in the monoclinic $\mathrm{P} 2_{1} / \mathrm{c}$ space group. Each asymmetric unit contains two discrete diastereomeric complexes, $[\mathrm{M} 1 \mathrm{HL}]^{+}$and $[\mathrm{M} 2 \mathrm{HL}]^{+}$, that are present as racemic mixtures of enantiomers in the unit cell. A single pendant thiosemicarbazonato arm is coordinated to the $\mathrm{M}^{2+}$ centre through the sulfur (S1) and azomethinic $\left(\mathrm{N}_{\mathrm{azo}}\right)$ nitrogen donor atoms (N5), along with the four macrocyclic $\left(\mathrm{N}_{\mathrm{mac}}\right)$ nitrogen atoms $(\mathrm{N} 1$, $\mathrm{N} 2$, N3 and N4), forming six five-membered chelate rings. The $\mathrm{Mn}^{2+}, \mathrm{Co}^{2+}$ and $\mathrm{Zn}^{2+}$ structures are consistent with the loss of one proton from the ligand. The C12-S1 bond lengths for the $\mathrm{Mn}^{2+}(1.745(2) \AA), \mathrm{Co}^{2+}(1.735(6) \AA)$ and $\mathrm{Zn}^{2+}(1.743(3) \AA)$ structures are indicative of more thiolate character than the thione character of the C18-S2 bond lengths (1.683(2) $\AA, 1.685(5) \AA$ and 1.687(3) $\AA$, respectively). Crystallographic data are shown in Table 1. Representations of the isostructural $[\mathrm{Mn} 1 \mathrm{HL}]^{+}$and $[\mathrm{Zn} 1 \mathrm{HL}]^{+}$complex cations are 
shown in Figure 2. A list of metal to donor bond lengths is given in Table 2. The donor atoms $\mathrm{N} 1, \mathrm{~N} 2, \mathrm{~N} 3, \mathrm{~N} 4, \mathrm{~N} 5$ and $\mathrm{S} 1$ are analogous to the donor atoms N11, N12, N13, N14, $\mathrm{N} 15$ and $\mathrm{S} 3$ of the Mn2, Co2 and Zn2 complexes.

Table 1. Experimental, crystallographic and refinement data for $[\mathrm{MnHL}]\left(\mathrm{BPh}_{4}\right),[\mathrm{CoHL}]\left(\mathrm{BPh}_{4}\right) \cdot\left(\mathrm{C}_{3} \mathrm{H}_{6} \mathrm{O}\right)$ and $[\mathrm{ZnHL}]\left(\mathrm{BPh}_{4}\right) \cdot 1.67\left(\mathrm{C}_{3} \mathrm{H}_{6} \mathrm{O}\right)$.

\begin{tabular}{|c|c|c|c|}
\hline & {$[\mathrm{MnHL}]\left(\mathrm{BPh}_{4}\right)$} & {$[\mathrm{CoHL}]\left(\mathrm{BPh}_{4}\right) \cdot\left(\mathrm{C}_{3} \mathrm{H}_{6} \mathrm{O}\right)$} & {$[\mathrm{ZnHL}]\left(\mathrm{BPh}_{4}\right) \cdot 1.67\left(\mathrm{C}_{3} \mathrm{H}_{6} \mathrm{O}\right)$} \\
\hline Empirical formula & $\mathrm{C}_{44} \mathrm{H}_{61} \mathrm{BMnN}_{10} \mathrm{~S}_{2}$ & $\mathrm{C}_{47} \mathrm{H}_{67} \mathrm{BCoN}_{10} \mathrm{OS}_{2}$ & $\mathrm{C}_{49} \mathrm{H}_{70.75} \mathrm{BN}_{10} \mathrm{O}_{1.67} \mathrm{~S}_{2} \mathrm{Zn}$ \\
\hline Formula weight & 859.89 & 921.96 & 966.86 \\
\hline Crystal system & Monoclinic & Monoclinic & Monoclinic \\
\hline Space group & $\mathrm{P} 21 / \mathrm{c}$ & $\mathrm{P} 21 / \mathrm{c}$ & $\mathrm{P} 21 / \mathrm{c}$ \\
\hline Temperature (K) & $123(2)$ & $173(2)$ & $123(1)$ \\
\hline a $(\AA)$ & $17.4842(3)$ & $17.2017(2)$ & $17.32220(10)$ \\
\hline b (̊̊) & $35.9904(5)$ & $35.8919(4)$ & $36.0585(2)$ \\
\hline c (̊̊) & $17.4662(3)$ & $17.3716(2)$ & $17.36950(10)$ \\
\hline$\alpha\left(^{\circ}\right)$ & 90 & 90 & 90 \\
\hline$\beta\left({ }^{\circ}\right)$ & $100.8860(10)$ & $102.2170(10)$ & $101.7190(10)$ \\
\hline$\gamma\left({ }^{\circ}\right)$ & 90 & 90 & 90 \\
\hline$V\left(\AA^{3}\right)$ & $10,793.1(3)$ & $10,482.4$ & $10,623.06(11)$ \\
\hline $\mathrm{Z}$ & 8 & 8 & 8 \\
\hline$D c\left(\mathrm{~g} \mathrm{~cm}^{-3}\right)$ & 1.058 & 1.168 & 1.209 \\
\hline Absorption coefficient $\left(\mathrm{mm}^{-1}\right)$ & 0.358 & 3.639 & 1.729 \\
\hline$F(000)$ & 3656 & 3928 & 4121 \\
\hline \multirow{2}{*}{ Angle range $2 \theta,^{\circ}$} & $\operatorname{MoK} \alpha$ & $\mathrm{CuK} \alpha$ & $\mathrm{CuK} \alpha$ \\
\hline & 6.630 to 55.754 & 7.168 to 154.048 & 7.012 to 154.846 \\
\hline Reflections collected & 143,110 & 102,026 & 115,251 \\
\hline \multirow{2}{*}{ Independent reflections } & 25,679 & 21,504 & 22,186 \\
\hline & {$[R(\mathrm{int})=0.0469]$} & {$[R(\mathrm{int})=0.0832]$} & {$[R(\mathrm{int})=0.0456]$} \\
\hline Final $R_{1}$ values $(I>2 \sigma(I))$ & 0.0440 & 0.0889 & 0.0572 \\
\hline Final $w R_{1}\left(F^{2}\right)$ values $(I>2 \sigma(I))$ & 0.1111 & 0.2389 & 0.1622 \\
\hline Final $R_{1}$ values (all data) & 0.0606 & 0.1252 & 0.0617 \\
\hline Final $w R_{1}\left(F^{2}\right)$ values (all data) & 0.1180 & 0.2764 & 0.1667 \\
\hline GoF on $\mathrm{F}^{2}$ & 1.076 & 1.036 & 1.023 \\
\hline CSD no. & $2,072,659$ & $2,072,660$ & $2,072,661$ \\
\hline
\end{tabular}

Table 2. Metal to donor bond lengths for $[\mathrm{Mn} 1 \mathrm{HL}]^{+},[\mathrm{Mn} 2 \mathrm{HL}]^{+},[\mathrm{Co} 1 \mathrm{HL}]^{+},[\mathrm{Co} 2 \mathrm{HL}]^{+},[\mathrm{Zn} 1 \mathrm{HL}]^{+}$and $[\mathrm{Zn} 2 \mathrm{HL}]^{+}$.

\begin{tabular}{|c|c|c|c|c|c|c|}
\hline & $\operatorname{Mn} 1(\AA ̊)$ & Mn2 (Å) & Co1 (Å) & Co2 (Å) & Zn1 (Å) & $\mathrm{Zn} 2(\AA)$ \\
\hline M-N1/11 & $2.362(2)$ & $2.397(1)$ & $2.331(4)$ & $2.325(4)$ & $2.340(2)$ & $2.393(2)$ \\
\hline M-N2/12 & $2.264(2)$ & $2.254(2)$ & $2.156(4)$ & $2.183(5)$ & $2.152(2)$ & $2.140(2)$ \\
\hline M-N3/13 & $2.501(2)$ & $2.471(2)$ & $2.620(4)$ & $2.317(4)$ & $2.737(2)$ & $2.630(2)$ \\
\hline M-N4/14 & $2.244(2)$ & $2.250(2)$ & $2.113(4)$ & $2.159(4)$ & $2.121(2)$ & $2.125(2)$ \\
\hline M-N5/15 & $2.257(2)$ & $2.218(2)$ & $2.120(4)$ & $2.087(4)$ & $2.147(2)$ & $2.130(2)$ \\
\hline M-S1/3 & $2.462(1)$ & $2.455(1)$ & $2.323(2)$ & $2.365(1)$ & $2.346(7)$ & $2.344(7)$ \\
\hline
\end{tabular}




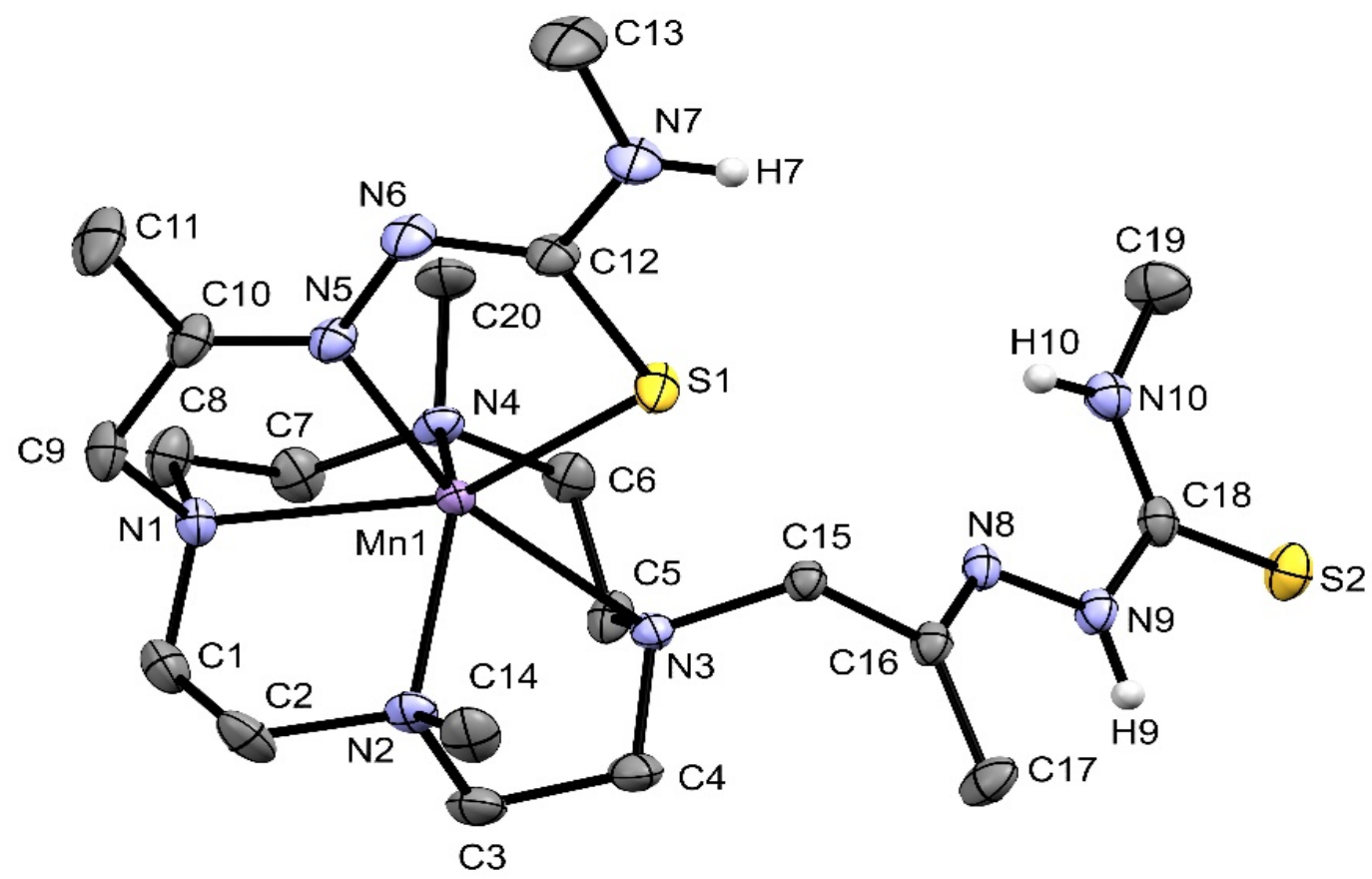

(a)

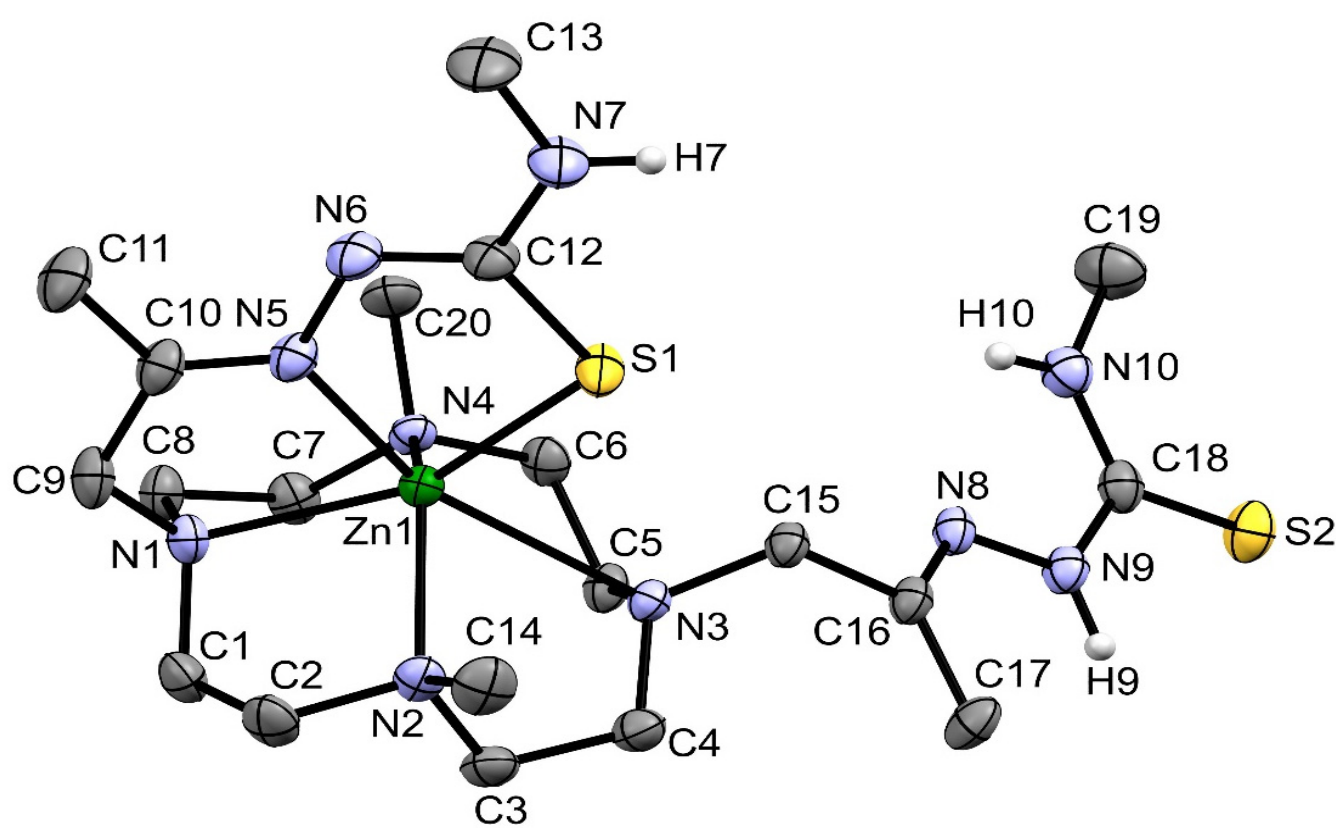

(b)

Figure 2. Single-crystal X-ray diffraction structure representations of the (a) $[\mathrm{Mn} 1 \mathrm{HL}]^{+}$and (b) $[\mathrm{Zn} 1 \mathrm{HL}]^{+}$complex cations at $30 \%$ thermal ellipsoid probability. Hydrogen atoms are omitted for clarity (except hydrogen atoms bound to nitrogen).

The bonds between the metal ions and N3/N13 are significantly longer than the other bonds between the metal and nitrogen donor atoms of the macrocycle. This is presumably a result of the steric effects of the uncoordinated thiosemicarbazone pendant arm. The metal to sulfur donor bond lengths are typical of $\mathrm{Mn}^{2+}$ and $\mathrm{Zn}^{2+}$ thiosemicarbazonato complexes [11,20]. The Mn1, Mn2, Zn1, Zn2 and Co1 ions sit above the plane defined by the four nitrogen atoms of the macrocycle by $1.1 \AA$, while the Co2 ion sits above the plane by $1.0 \AA$.

The torsion angles defined by the $\mathrm{N}-\mathrm{C}-\mathrm{C}-\mathrm{N}$ bonds in the macrocycle are described as $\delta$ (positive value) or $\lambda$ (negative value) [69]. The average $\mathrm{N}-\mathrm{C}-\mathrm{C}-\mathrm{N}$ torsion angles in the 
[Mn1HL $^{+}$and $[\mathrm{Mn} 2 \mathrm{HL}]^{+}$complexes are $\pm 58^{\circ}$ and in $[\mathrm{Zn} 1 \mathrm{HL}]^{+}$and $[\mathrm{Zn} 2 \mathrm{HL}]^{+}$are $\pm 57^{\circ}$. The trigonal distortion from an idealised octahedral geometry can be analysed using the dihedral angle $(\theta)$ defined as the twist angle between the corners of the trigonal planes [70]. The trigonal planes of the complexes are defined by N1-N4-N5 and N2-N3-S1 (Figure 3).

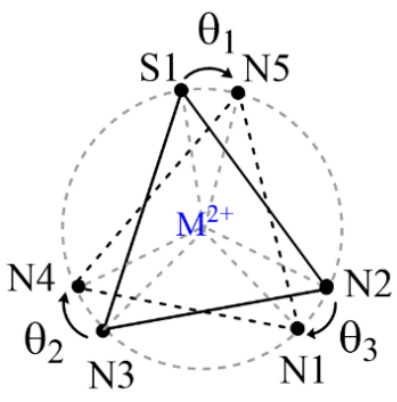

$\Delta$

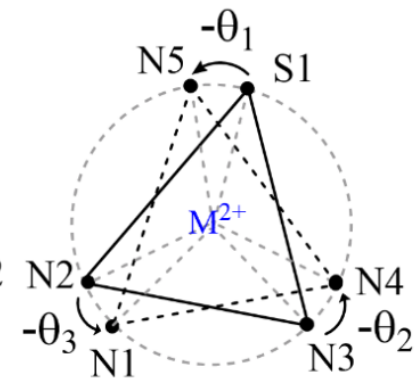

$\Lambda$

Figure 3. A representation of the torsion angles defined by the two trigonal planes.

A positive torsion angle indicates the $\Delta$ enantiomer, and a negative torsion value indicates the $\Lambda$ enantiomer. A trigonal prismatic geometry is indicated by a torsion angle of $0^{\circ}$, whereas a torsion angle of $60^{\circ}$ indicates an octahedral geometry. The average torsion angles within the complexes are shown in Table 3. Interestingly, [Mn1HL] ${ }^{+}$and [Zn1HL] $]^{+}$ exist as the $\Delta(\delta, \delta, \delta, \delta)$ and $\Lambda(\lambda, \lambda, \lambda, \lambda)$ enantiomers, and [Mn2HL] ${ }^{+}$and $[\mathrm{Zn} 2 \mathrm{HL}]^{+}$exist as the $\Delta(\lambda, \lambda, \lambda, \lambda)$ and $\Lambda(\delta, \delta, \delta, \delta)$ enantiomers.

Table 3. The dihedral angles between the two trigonal planes in the $[\mathrm{Mn} 1 \mathrm{HL}]^{+},[\mathrm{Mn} 2 \mathrm{HL}]^{+},[\mathrm{Co} 1 \mathrm{HL}]^{+}$, $[\mathrm{Co} 2 \mathrm{HL}]^{+},[\mathrm{Zn} 1 \mathrm{HL}]^{+}$and $[\mathrm{Zn} 2 \mathrm{HL}]^{+}$metal centres.

\begin{tabular}{ccccc}
\hline & $\boldsymbol{\theta}_{\mathbf{1}}\left({ }^{\circ}\right)$ & $\boldsymbol{\theta}_{\mathbf{2}}\left({ }^{\circ}\right)$ & $\boldsymbol{\theta}_{\mathbf{3}}\left({ }^{\circ}\right)$ & $\operatorname{Av}\left({ }^{\circ}\right)$ \\
\hline Mn1 & 35.7 & 20.2 & 8.1 & 21.4 \\
Mn2 & 32.0 & 18.6 & 7.0 & 19.2 \\
Co1 & 37.5 & 21.4 & 12.3 & 23.7 \\
Co2 & 40.7 & 31.2 & 20.9 & 30.9 \\
Zn1 & 37.4 & 21.7 & 13.1 & 24.1 \\
Zn2 & 33.7 & 21.5 & 12.6 & 22.6 \\
\hline
\end{tabular}

Representations of the $[\mathrm{Co} 1 \mathrm{HL}]^{+}$and $[\mathrm{Co} 2 \mathrm{HL}]^{+}$complex cations are shown in Figure 4. The [Co1HL] ${ }^{+}$complex occurs as the $\Delta(\delta, \delta, \delta, \delta)$ and $\Lambda(\lambda, \lambda, \lambda, \lambda)$ enantiomeric pair with average $\mathrm{N}-\mathrm{C}-\mathrm{C}-\mathrm{N}$ torsion angles of $\pm 55^{\circ}$. Interestingly, the [Co2HL $]^{+}$complex is a racemic mixture of the $\Delta(\lambda, \lambda, \lambda, \delta)$ and $\Lambda(\delta, \delta, \delta, \lambda)$ enantiomeric pair. The N-C-C-N torsion angles in the $\Delta(\lambda, \lambda, \lambda, \delta)$ enantiomer are $48.1^{\circ}, 40.7^{\circ}, 48.8^{\circ}$ and $-60.2^{\circ}$. This results in a Co2-N13 bond length of 2.317(4) $\AA$, which is significantly shorter than the Co1-N3 bond length of $2.610(4) \AA$. The average dihedral angle for $[\mathrm{Co} 2 \mathrm{HL}]^{+}$is $30.9^{\circ}$, resulting in an intermediate geometry between trigonal prismatic and octahedral. The change in chirality probably reflects the competition between steric effects imposed by the ligand and the metal to donor atom bond length requirements of each of the complexes. Experimentally observed $\mathrm{Co}^{2+}$ complexes with $(\lambda, \lambda, \lambda, \delta)$ and $(\delta, \delta, \delta, \lambda)$ isomers have been reported previously in a complex with tetraethylcyclen and proline [71]. 


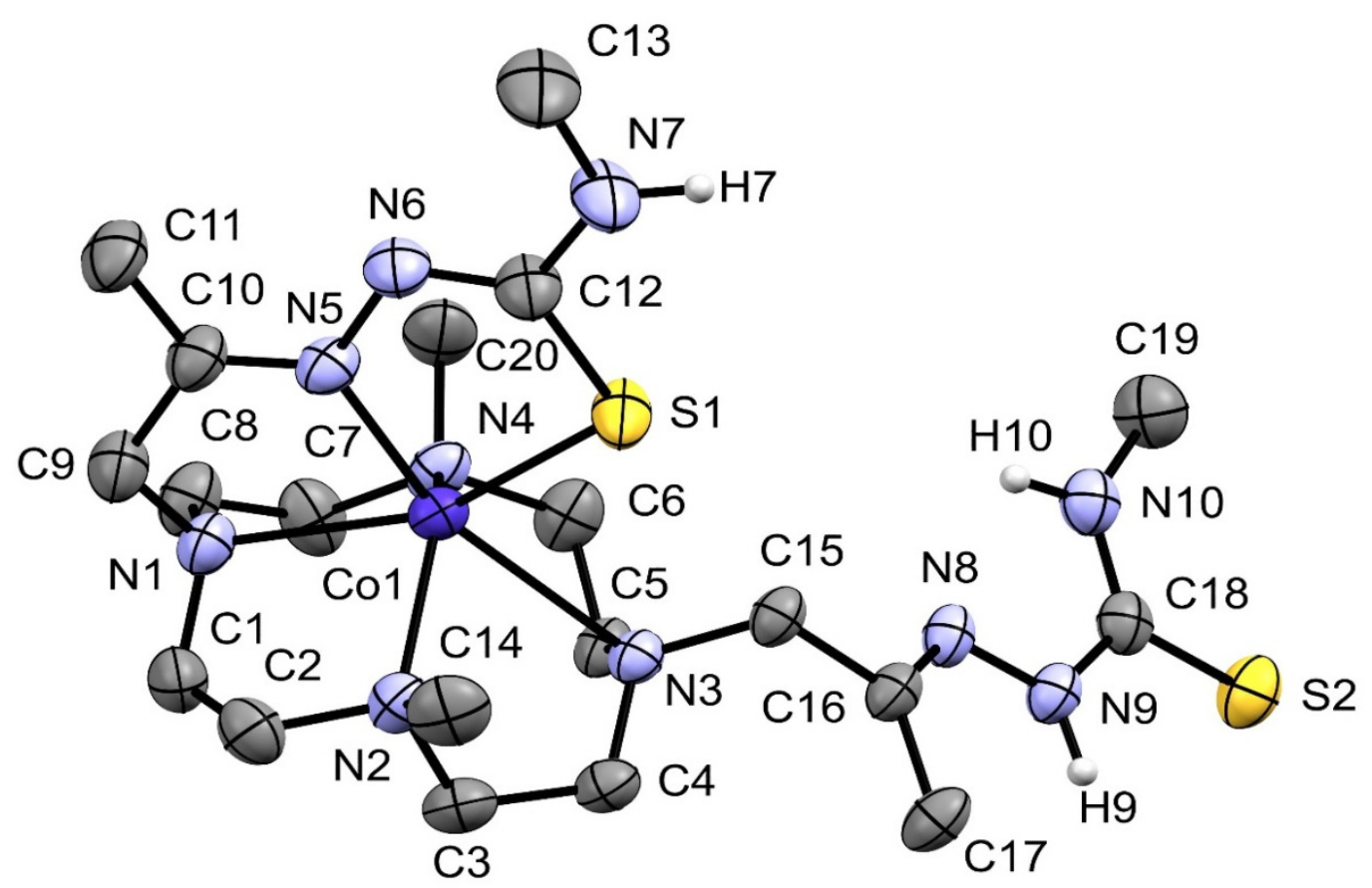

(a)

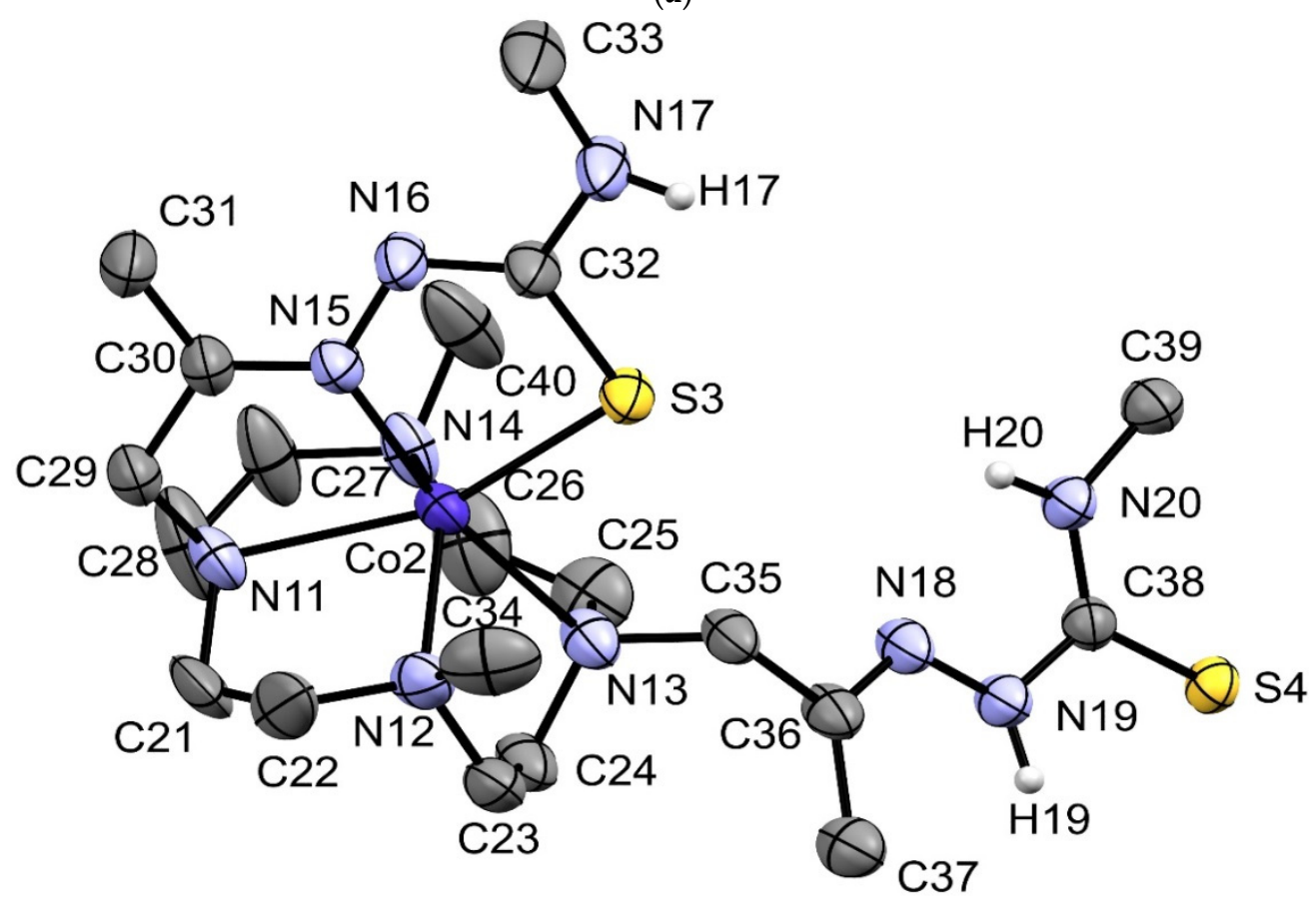

(b)

Figure 4. Single-crystal X-ray diffraction structure representations of the (a) $[\mathrm{Co} 1 \mathrm{HL}]^{+}$and (b) $[\mathrm{Co} 2 \mathrm{HL}]^{+}$complex cations at $30 \%$ thermal ellipsoid probability. Hydrogen atoms are omitted for clarity (except hydrogen atoms bound to nitrogen).

Several instances of trigonal prismatic high-spin $3 \mathrm{~d}^{5} \mathrm{Mn}^{2+}$, high-spin $3 \mathrm{~d}^{7} \mathrm{Co}^{2+}$ and $3 \mathrm{~d}^{10} \mathrm{Zn}^{2+}$ azamacrocyclic complexes have been reported [72-77]. While most six-coordinate complexes have a distinct octahedral preference over trigonal prismatic, high-spin $\mathrm{d}^{5}$ and $\mathrm{d}^{10}$ electron-configurations have no octahedral preference due to the absence of crystal field stabilisation energy, and high-spin $\mathrm{d}^{7}$ configurations have only a marginal preference [78]. A trigonal prismatic geometry can be forced upon $\mathrm{Co}^{2+}$ complexes by sterically constrained pendant arms, whereas two discrete ligands can give trigonal prismatic com- 
plexes with $\mathrm{Mn}^{2+}$ and $\mathrm{Zn}^{2+}$, including the formation of a $\mathrm{Mn}^{2+}$ complex with an $\mathrm{N}_{4} \mathrm{~S}_{2}$ donor sphere $[72,73,76,77]$. Only two $\mathrm{N}_{5} \mathrm{~S}$ cyclen-based complexes have been previously reported with $\mathrm{Co}^{2+}$ and $\mathrm{Zn}^{2+}$, both with octahedral geometry $[79,80] . \mathrm{H}_{2} \mathbf{L}$ is the first example of an azamacrocyclic $\mathrm{N}_{5} \mathrm{~S}$ donor for $\mathrm{Mn}^{2+}$. A trigonal prismatic $\mathrm{Zn}^{2+}$ complex has been previously reported with a $\mathrm{N}_{5} \mathrm{O}$ ligand containing a single pendant arm [75].

\subsection{Magnetic Susceptibility}

The distorted coordination geometries of the $[\mathrm{MnHL}]\left(\mathrm{BPh}_{4}\right)$ and $[\mathrm{CoHL}]\left(\mathrm{BPh}_{4}\right) \mathrm{com}$ plexes suggested that the metal ions were high-spin $3 \mathrm{~d}^{5}$ and $3 \mathrm{~d}^{7}$, respectively. To confirm this hypothesis, the magnetic susceptibility of both the $\mathrm{Mn}^{2+}$ and $\mathrm{Co}^{2+}$ complexes were measured. The [MnHL] $\left(\mathrm{BPh}_{4}\right)$ complex had a magnetic moment of 5.82 B.M corresponding to five unpaired electrons $\left(\mu_{\mathrm{s}}=5.92 \mathrm{~B} . \mathrm{M}\right.$.). The $[\mathrm{CoHL}]\left(\mathrm{BPh}_{4}\right)$ complex had a magnetic moment of 4.24 B.M. corresponding to three unpaired electrons ( $\mu_{\mathrm{s}}=3.87$ B.M.). The difference from the spin-only value is due to the mixing of angular momentum from the excited state and spin-orbit coupling [81]. The $\mathrm{Co}^{2+}$ value indicates a spin quartet ground state, obtained from six-coordinate octahedral or trigonal prismatic geometry [82].

\subsection{Density Functional Theory Calculations}

Complexes incorporating the cyclen scaffold with pendant groups are known to have multiple stereoisomeric forms that result from the combination of the two chiral elements [83]. The diastereomers can have distinctly different coordination geometries and properties [77,84]. Furthermore, formation of a predominant diastereoisomer can result when there is a free-energy difference between the diastereomers [85,86]. Density functional theory (DFT) calculations were used to investigate the energetics of each species identified from the X-ray crystallography. The calculations were performed using the Becke, 3-parameter, Lee-Yang-Parr (B3LYP) functional for all complexes investigated. The standard Ahlrichs valence triple- $\xi$ including polarization functions (TZVP) basis set was used for the high-spin $\mathrm{Co}^{2+}$ complexes and the DGDZVP basis set for the $\mathrm{Zn}^{2+}$ complexes. These combinations of functional and basis sets were chosen because they have shown good agreement with experimental values for similar combinations of ligands and metals [87,88]. For comparison with the XRD data, values for selected bond lengths of the optimised structures are shown in Table 4 . The optimised geometries of $[\mathrm{Co} 1 \mathrm{HL}]^{+},[\mathrm{Co} 2 \mathrm{HL}]^{+},[\mathrm{Zn} 1 \mathrm{HL}]^{+}$ and $[\mathrm{Zn} 2 \mathrm{HL}]^{+}$are provided in Figures S16-S23. A bond length difference of $\sim 0.074 \AA$ for $\mathrm{Zn}-\mathrm{S}$ and $\sim 0.078 \AA$ for $\mathrm{Zn}-\mathrm{N}_{\mathrm{mac}}$ and $\mathrm{Zn}-\mathrm{N}_{\text {azo }}$ was observed between the DFT optimised and XRD experimental values that was attributed to solvent effects.

Table 4. Selected bond lengths $(\AA)$ of the optimised and XRD structures of $[\mathrm{Co} 1 \mathrm{HL}]^{+},[\mathrm{Co} 2 \mathrm{HL}]^{+},[\mathrm{Zn} 1 \mathrm{HL}]^{+}$and $[\mathrm{Zn} 2 \mathrm{HL}]^{+}$.

\begin{tabular}{ccccccccc}
\hline & Zn1 XRD & Zn1 DFT & Zn2 XRD & Zn2 DFT & Co1 XRD & Co1 DFT & Co2 XRD & Co2 DFT \\
\hline M-N1/N11 & $2.340(2)$ & 2.390 & $2.393(2)$ & 2.411 & $2.331(4)$ & 2.351 & $2.325(4)$ & 2.402 \\
M-N2/N12 & $2.151(2)$ & 2.240 & $2.140(2)$ & 2.260 & $2.156(4)$ & 2.248 & $2.183(5)$ & 2.259 \\
M-N3/N13 & $2.737(2)$ & 2.727 & $2.630(2)$ & 2.701 & $2.620(4)$ & 2.680 & $2.317(4)$ & 2.400 \\
M-N4/N14 & $2.120(2)$ & 2.228 & $2.125(2)$ & 2.238 & $2.113(4)$ & 2.217 & $2.159(4)$ & 2.239 \\
M-N5N/15 & $2.147(2)$ & 2.211 & $2.130(2)$ & 2.212 & $2.120(4)$ & 2.164 & $2.087(4)$ & 2.128 \\
M-S1/S3 & $2.346(7)$ & 2.420 & $2.344(7)$ & 2.419 & $2.323(2)$ & 2.401 & $2.365(1)$ & 2.412 \\
\hline
\end{tabular}

DFT analysis of the $[\mathrm{ZnHL}]^{+}$complexes in the presence of water indicated four energy minima corresponding to the following diastereomeric pairs: $\Delta(\delta, \delta, \delta, \delta)$ and $\Lambda(\lambda, \lambda, \lambda, \lambda)$ for [Zn1HL $]^{+}$, and $\Delta(\lambda, \lambda, \lambda, \lambda)$ and $\Lambda(\delta, \delta, \delta, \delta)$ for $[\mathrm{Zn} 2 \mathrm{HL}]^{+}$. According to these calculations, the minimum energy conformation corresponds to the $\Lambda(\lambda, \lambda, \lambda, \lambda)$ isomer, with the relative energies of the $\Delta(\delta, \delta, \delta, \delta), \Delta(\lambda, \lambda, \lambda, \lambda)$ and $\Lambda(\delta, \delta, \delta, \delta)$ isomers being $0.34,1.27$ and $2.53 \mathrm{~kJ} \mathrm{~mol}^{-1}$, respectively. The optimisation of the $\mathrm{Co}^{2+}$ structures indicated that the minimum energy conformation corresponds to the $\Delta(\delta, \delta, \delta, \delta)$ isomer, with the relative energies of the $\Lambda(\lambda, \lambda, \lambda, \lambda), \Delta(\lambda, \lambda, \lambda, \delta)$ and $\Lambda(\delta, \delta, \delta, \lambda)$ isomers being $4.17,8.14$ and $8.14 \mathrm{~kJ} \mathrm{~mol}^{-1}$, respectively. 


\subsection{Radiolabelling with ${ }^{68} \mathrm{Ga}^{3+}$}

Preliminary radiolabelling studies were performed with ${ }^{68} \mathrm{Ga}^{3+}$ eluted from a ${ }^{68} \mathrm{Ge} /{ }^{68} \mathrm{Ga}$ generator. The eluate was buffered with $1 \mathrm{M}$ sodium acetate to $\mathrm{pH} 3.5$ or 6 and reacted with $\mathrm{H}_{2} \mathbf{L}(0.5,5,50$ and $500 \mu \mathrm{M})$ at ambient temperature, 40 and $90{ }^{\circ} \mathrm{C}$ for $10 \mathrm{~min}$. The $68 \mathrm{~min}$ half-life of ${ }^{68} \mathrm{Ga}^{3+}$ necessitates relatively short reaction times. The reaction mixtures were analysed by radio-HPLC, which showed a single product with a retention time $\left(R_{\mathrm{T}}\right)$ of $5.3 \mathrm{~min}$ while there was negligible retention of the $\left[{ }^{68} \mathrm{Ga}\right] \mathrm{Ga}^{3+}$ ion on the $\mathrm{C} 18$ column $\left(R_{\mathrm{T}}=1.5 \mathrm{~min}\right)$. The synthesis of the non-radioactive $\mathrm{Ga}^{3+}$ complex was attempted but isolation was unsuccessful. The radiolabelling reaction with DOTA was performed previously under the same conditions and used as a comparison [49]. The percentage of ${ }^{68} \mathrm{Ga}^{3+}$ incorporation is dependent on ligand concentration, $\mathrm{pH}$ and temperature. ${ }^{68} \mathrm{Ga}^{3+}$ incorporation was investigated at both $\mathrm{pH} 3.5$ and $\mathrm{pH} 6$ at $50 \mu \mathrm{M}$ with an activity to ligand ratio of $0.2 \mathrm{MBq} \mathrm{nmol}^{-1}$ (Figure 5). A radiochemical yield (RCY) $>95 \%$ was achieved at $\mathrm{pH} 6$ at both 40 and $90{ }^{\circ} \mathrm{C}$ but required a ligand concentration of $500 \mu \mathrm{M}$ (Table 5). At $\mathrm{pH} 3.5$, a RCY $>95 \%$ was achieved with a ligand concentration of $50 \mu \mathrm{M}$ at $90^{\circ} \mathrm{C}$.

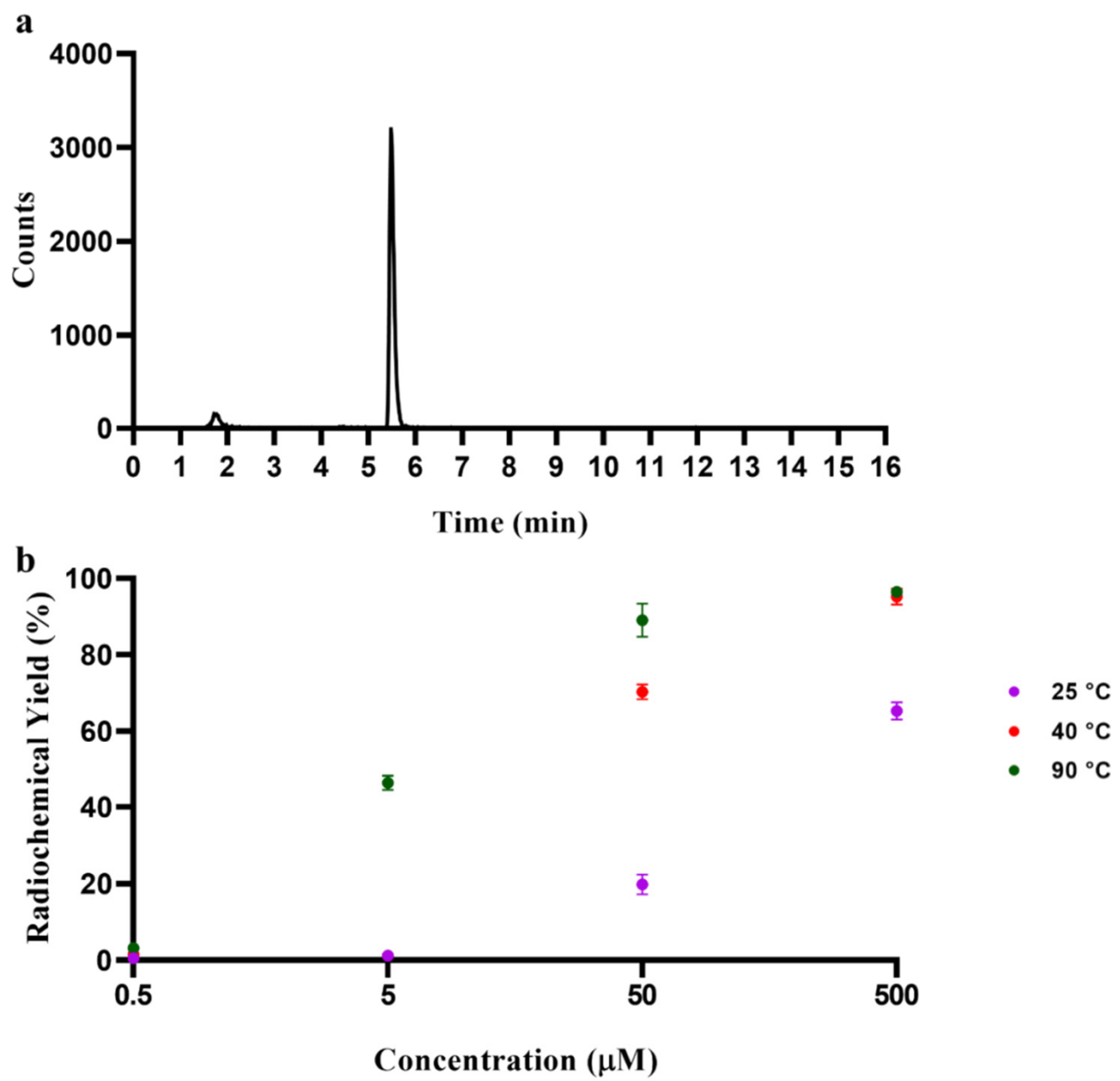

Figure 5. (a) Radio-HPLC chromatogram of the reaction between ${ }^{68} \mathrm{Ga}^{3+}(1.2 \mathrm{MBq})$ and $\mathrm{H}_{2} \mathbf{L}(50 \mu \mathrm{M})$ after $10 \mathrm{~min}$ at $\mathrm{pH} 6$ and $90{ }^{\circ} \mathrm{C}$. (b) Radiochemical yields for the reaction of ${ }^{68} \mathrm{Ga}^{3+}$ at various concentrations $(0.5$ to $500 \mu \mathrm{M})$ and temperatures $\left(25,40\right.$ and $\left.90{ }^{\circ} \mathrm{C}\right)$ at $\mathrm{pH} 6$ after $10 \mathrm{~min}$. 
Table 5. The radiochemical yields for the reaction of ${ }^{68} \mathrm{Ga}^{3+}$ with $\mathrm{H}_{2} \mathbf{L}(50 \mu \mathrm{M})$ and DOTA $(50 \mu \mathrm{M})$ at $\mathrm{pH} 3.5$ and $\mathrm{pH} 6$ and various temperatures $\left(25,40\right.$ and $\left.90^{\circ} \mathrm{C}\right)$ [49].

\begin{tabular}{|c|c|c|c|c|}
\hline & \multicolumn{2}{|c|}{$\mathrm{H}_{2} \mathrm{~L}$} & \multicolumn{2}{|c|}{ DOTA } \\
\hline & pH 3.5 & pH 6 & pH 3.5 & pH 6 \\
\hline $25{ }^{\circ} \mathrm{C}$ & $1.8 \pm 1.7$ & $19.8 \pm 2.6$ & $86.7 \pm 5.0$ & $73.2 \pm 6.4$ \\
\hline $40^{\circ} \mathrm{C}$ & $60.4 \pm 3.1$ & $70.3 \pm 1.9$ & - & - \\
\hline $90^{\circ} \mathrm{C}$ & $95.1 \pm 2.3$ & $89.0 \pm 4.3$ & $95.3 \pm 0.9$ & $97.2 \pm 0.3$ \\
\hline
\end{tabular}

Under similar conditions, DOTA required concentrations of $50 \mu \mathrm{M}$ or above to reach yields $>95 \%$, similar to $\mathrm{H}_{2} \mathbf{L}$. At pH 6, a RCY > 95\% for DOTA was achieved with a concentration of $500 \mu \mathrm{M}$ at $25{ }^{\circ} \mathrm{C}$ or $50 \mu \mathrm{M}$ at $90{ }^{\circ} \mathrm{C}$ [49]. The RCY for DOTA with a concentration of $50 \mu \mathrm{M}$ at $25^{\circ} \mathrm{C}$ is $\sim 87 \%$ whereas $\mathrm{H}_{2} \mathbf{L}$ achieved only $2 \% \mathrm{RCY}$ under the same conditions. These results demonstrate that $\mathrm{H}_{2} \mathbf{L}$ radiolabelling with ${ }^{68} \mathrm{Ga}^{3+}$ is temperature dependent at both $\mathrm{pH}$ values studied, and that it does not possess the radiolabelling efficiency properties to be a potential alternative chelator for ${ }^{68} \mathrm{Ga}^{3+}$ radiolabelling. This is perhaps unsurprising given the combination of soft base sulfur donor atoms and the hard acid $\mathrm{Ga}^{3+}$ [89]. A ligand design incorporating oxygen donor-containing semicarbazone pendant arms may be better suited for use in ${ }^{68} \mathrm{Ga}^{3+}$ radiopharmaceuticals [90].

\section{Materials and Methods}

\subsection{General Procedures}

Reagents were purchased from standard commercial sources unless otherwise stated and used without further purification. Cyclen was purchased from Strem Chemicals (Newburyport, MA, USA). Nuclear magnetic resonance (NMR) data were collected on a Bruker AVANCE III $600\left({ }^{1} \mathrm{H}\right.$ at $600.27 \mathrm{MHz},{ }^{13} \mathrm{C}\left\{{ }^{1} \mathrm{H}\right\}$ at $150.95 \mathrm{MHz}$ ) (Bruker, Billerica, MA, USA). Spectra were processed using MestReNova 10.0 software. DMSO- $d_{6}$ was obtained from Cambridge Isotope Laboratories Inc. Chemical shifts $(\delta)$ are reported in parts per million (ppm) with respect to TMS and are referenced to residual solvent peaks. Coupling constants $(J)$ are reported in Hz. Unless specified, all NMR spectra were recorded at $25^{\circ} \mathrm{C}$. Low-resolution mass spectrometry (LR-MS) was carried out using an Agilent 1260 Infinity liquid chromatograph system coupled with a 6120 series quadrupole mass spectrometer (Agilent Technologies, Santa Clara, CA, USA) in MeOH using ESI. High-resolution mass spectrometry (HR-MS) was carried out with an Agilent 6540 UHD Accurate Mass Q-TOF LCMS (Agilent Technologies, Santa Clara, CA, USA). The mass spectrometer was fitted with the Agilent Jet Stream Source using ESI. Positive detection is shown by the charge on the ion, e.g., $[\mathrm{M}+\mathrm{H}]^{+}$for a positive protonated ion. All calculated values were determined using the PerkinElmer software ChemDraw ${ }^{\circledR}$ Professional 19.0 to four decimal places. HPLC traces of both radiolabelled and non-radiolabelled complexes were acquired using a Shimadzu HPLC system (Shimadzu, Kyoto, Japan) with a Phenomenex Luna C18(2) column $(4.6 \mathrm{~mm} \times 150 \mathrm{~mm}, 5 \mu \mathrm{m})$, a $1 \mathrm{~mL} / \mathrm{min}$ flow rate gradient elution of $0.05 \%$ TFA in $5 \% \mathrm{MeCN}$ in $\mathrm{H}_{2} \mathrm{O}$ to $100 \% \mathrm{MeCN}$ over 15 min at $25^{\circ} \mathrm{C}$ with UV spectroscopic detection at $254 \mathrm{~nm}$ and $280 \mathrm{~nm}$. Data were processed and analysed using Laura radio chromatography software (Lablogic, Brandon, FL, USA). Magnetic susceptibility was measured at room temperature by calibrating a Johnson Matthey MSB balance with $\left[\mathrm{Ni}(\mathrm{en})_{3}\right] \mathrm{S}_{2} \mathrm{O}_{3}$ at $295 \mathrm{~K}$ and diamagnetic corrections of the paramagnetic susceptibilities were calculated using standard Pascal's constants [91,92].

\subsection{Synthesis}

1,1'-(4,10-Dimethyl-1,4,7,10-tetraazacyclododecane-1,7-diyl)bis(propan-2-one) (1) was prepared according to previously published methods [63].

$\mathrm{H}_{2} \mathbf{L}$ : To a solution of $\mathbf{1}(1.432 \mathrm{~g}, 4.582 \mathrm{mmol}, 1$ equiv.) and 4-methyl-3-thiosemicarbazide $(1.060 \mathrm{~g}, 10.08 \mathrm{mmol}, 2.2$ equiv.) in EtOH $(40 \mathrm{~mL})$ was added 7 drops of glacial acetic acid. The solution was stirred for $72 \mathrm{~h}$ at room temperature. The precipitate was collected on a vacuum glass frit, washed with EtOAc and $\mathrm{Et}_{2} \mathrm{O}$ to afford a light-yellow solid $(0.6532 \mathrm{~g}$, 
$1.342 \mathrm{mmol}, 29 \%)$. RP-HPLC: $\mathrm{R}_{\mathrm{T}}=5.27 \mathrm{~min} ;{ }^{1} \mathrm{H}$ NMR $\left(600 \mathrm{MHz}, \mathrm{DMSO}-\mathrm{d}_{6}\right): \delta=1.96(\mathrm{~s}, 6 \mathrm{H}$, $\left.\mathrm{CH}_{2} \mathrm{CCH}_{3}\right), 2.45\left(\mathrm{~s}, 6 \mathrm{H}, \mathrm{CH}_{2} \mathrm{NCH}_{3}\right), 2.75\left(\mathrm{~s}, 16 \mathrm{H}, \mathrm{NCH}_{2} \mathrm{CH}_{2} \mathrm{~N}\right), 2.98\left(\mathrm{~d}, 6 \mathrm{H}, \mathrm{CSNCH}_{3}\right.$, $\left.{ }^{3} J_{\mathrm{H}-\mathrm{H}}=4.6 \mathrm{~Hz}\right), 3.34\left(\mathrm{~s}, 4 \mathrm{H}, \mathrm{NCH}_{2} \mathrm{C}\right), 8.18\left(\mathrm{~d}, 2 \mathrm{H}, \mathrm{CSNHCH}_{3}{ }^{3} \mathrm{~J}_{\mathrm{H}-\mathrm{H}}=4.6 \mathrm{~Hz}\right), 10.03(\mathrm{~s}, 2 \mathrm{H}$, NNHCS $) ;{ }^{13} \mathrm{C}\left\{{ }^{1} \mathrm{H}\right\}$ NMR $\left(150 \mathrm{MHz}, \mathrm{DMSO}_{6}\right): \delta=15.8\left(\mathrm{CH}_{2} \mathrm{CCH}_{3}\right), 30.9\left(\mathrm{CSNCH}_{3}\right)$, $40.1\left(\mathrm{CH}_{2} \mathrm{NCH}_{3}\right), 49.8\left(\mathrm{NCH}_{2} \mathrm{CH}_{2} \mathrm{~N}\right), 63.3\left(\mathrm{NCH}_{2} \mathrm{C}\right), 150.8(\mathrm{C}=\mathrm{N}), 178.8(\mathrm{C}=\mathrm{S}) ; \mathrm{HRMS}(\mathrm{ESI})$ $\left[\mathrm{H}_{2} \mathbf{L}+\mathrm{H}\right]^{+}: m / z=487.3199$ (experimental), 487.3035 (calculated).

General Procedure for the Synthesis of the Complexes

To a solution of $\mathrm{H}_{2} \mathbf{L}(0.0500 \mathrm{~g}$, $0.103 \mathrm{mmol}, 1$ equiv. $)$ in $\mathrm{MeOH}(4 \mathrm{~mL})$ was added a solution of $\mathrm{Mn}(\mathrm{OAc})_{2} \cdot 4 \mathrm{H}_{2} \mathrm{O}, \mathrm{Co}(\mathrm{OAc})_{2} \cdot 4 \mathrm{H}_{2} \mathrm{O}$ or $\mathrm{Zn}(\mathrm{OAc})_{2} \cdot 2 \mathrm{H}_{2} \mathrm{O}(0.103 \mathrm{mmol}, 1$ equiv. $)$ in $\mathrm{MeOH}(2 \mathrm{~mL})$, and the solution was left to stir for $17 \mathrm{~h}$ at ambient temperature. A solution of $\mathrm{NaBPh}_{4}(0.0352 \mathrm{~g}, 0.103 \mathrm{mmol}, 1$ equiv.) in $\mathrm{MeOH}(3 \mathrm{~mL})$ was added and the resulting suspension was stirred for an additional $4 \mathrm{~h}$ at ambient temperature. The product was collected on a glass frit and washed with $\mathrm{Et}_{2} \mathrm{O}$. $\left([\mathrm{MnHL}]\left(\mathrm{BPh}_{4}\right): 0.0498 \mathrm{~g}, 0.0579 \mathrm{mmol}\right.$, $56 \%),\left([\mathrm{CoHL}]\left(\mathrm{BPh}_{4}\right): 0.0271 \mathrm{~g}, 0.0314 \mathrm{mmol}, 30 \%\right),\left([\mathrm{ZnHL}]\left(\mathrm{BPh}_{4}\right): 0.0565 \mathrm{~g}, 0.0649 \mathrm{mmol}\right.$, $63 \%)$. The solids were each dissolved in acetone $(1 \mathrm{~mL})$ and $\mathrm{Et}_{2} \mathrm{O}$ was vapour diffused to form crystals suitable for single-crystal X-ray diffraction. RP-HPLC [MnHL] $\left[\mathrm{BPh}_{4}\right]$ : $\mathrm{R}_{\mathrm{T}}=6.06 \mathrm{~min} ;[\mathrm{CoHL}]\left[\mathrm{BPh}_{4}\right]: \mathrm{R}_{\mathrm{T}}=6.05 \mathrm{~min} ;[\mathrm{ZnHL}]\left[\mathrm{BPh}_{4}\right]: \mathrm{R}_{\mathrm{T}}=6.01 \mathrm{~min} ;{ }^{1} \mathrm{H} \mathrm{NMR}$ [ZnHL] $\left(\mathrm{BPh}_{4}\right)\left(600 \mathrm{MHz}, \mathrm{DMSO}-\mathrm{d}_{6}\right): \delta=1.96\left(\mathrm{~s}, 3 \mathrm{H}, \mathrm{CH}_{3}\right), 2.03\left(\mathrm{~s}, 3 \mathrm{H}, \mathrm{CH}_{3}\right), 2.31(\mathrm{~s}, 6 \mathrm{H}$, $\left.\mathrm{CH}_{3}\right), 2.40,2.59,2.72,2.88,3.04\left(\mathrm{~m}, 16 \mathrm{H}, \mathrm{NCH}_{2} \mathrm{CH}_{2} \mathrm{~N}\right), 2.74\left(\mathrm{~d}, 3 \mathrm{H}, \mathrm{CH}_{3},{ }^{3} \mathrm{~J}_{\mathrm{H}-\mathrm{H}}=4.3 \mathrm{~Hz}\right)$, $2.98\left(\mathrm{~d}, 3 \mathrm{H}, \mathrm{CH}_{3},{ }^{3} J_{\mathrm{H}-\mathrm{H}}=4.5 \mathrm{~Hz}\right), 3.40\left(\mathrm{~s}, 2 \mathrm{H}, \mathrm{NCH}_{2} \mathrm{CN}\right), 3.60\left(\mathrm{~s}, 2 \mathrm{H}, \mathrm{NCH}_{2} \mathrm{CN}\right), 6.78(\mathrm{t}, 4 \mathrm{H}$, $\left.\mathrm{ArH},{ }^{3} J_{\mathrm{H}-\mathrm{H}}=7.0 \mathrm{~Hz}\right), 6.92\left(\mathrm{t}, 8 \mathrm{H}, \mathrm{ArH},{ }^{3} J_{\mathrm{H}-\mathrm{H}}=7.5 \mathrm{~Hz}\right), 7.17(\mathrm{~m}, 8 \mathrm{H}, \mathrm{ArH}), 6.56(\mathrm{q}, 1 \mathrm{H}$, $\left.\mathrm{NHCH}_{3}\right), 8.22\left(\mathrm{q} 1 \mathrm{H}, \mathrm{NHCH}_{3}\right), 10.01(\mathrm{~s}, 2 \mathrm{H}, \mathrm{NH}) ;{ }^{13} \mathrm{C}\left\{{ }^{1} \mathrm{H}\right.$ NMR $\left(150 \mathrm{MHz}, \mathrm{DMSO}-\mathrm{d}_{6}\right)$ : $\delta=17.2\left(\mathrm{CH}_{2} \mathrm{CCH}_{3}\right), 18.1\left(\mathrm{CH}_{2} \mathrm{CCH}_{3}\right), 28.9\left(\mathrm{CSNCH}_{3}\right), 30.7\left(\mathrm{CSNCH}_{3}\right), 45.2\left(\mathrm{CH}_{2} \mathrm{NCH}_{3}\right)$, 51.8, 54.1, $54.9\left(\mathrm{NCH}_{2} \mathrm{CH}_{2} \mathrm{~N}\right), 58.7\left(\mathrm{NCH}_{2} \mathrm{CN}\right), 61.3\left(\mathrm{NCH}_{2} \mathrm{CN}\right), 121.5(\mathrm{ArC}), 125.3(\mathrm{ArC})$, $135.5(\mathrm{ArC}), 148.6(\mathrm{C}=\mathrm{N}), 157.3(\mathrm{C}=\mathrm{N}), 163.2(\mathrm{ArCB}), 179.8(\mathrm{C}=\mathrm{S})$; HRMS (ESI) [ZnHL + H] $]^{+}$: $\mathrm{m} / \mathrm{z}=549.2249$ (experimental), 549.2249 (calculated); $[\mathrm{MnHL}+\mathrm{H}]^{+}: \mathrm{m} / \mathrm{z}=540.2335$ (experimental), 540.2338 (calculated); [CoHL $+\mathrm{H}]^{+}: m / z=544.2298$ (experimental), 544.2289 (calculated).

\subsection{Radiolabelling with ${ }^{68} \mathrm{Ga}$}

${ }^{68} \mathrm{Ga}$ was eluted from an Eckert and Ziegler ${ }^{68} \mathrm{Ge} /{ }^{68} \mathrm{Ga}$ generator system (Eckert and Ziegler, Berlin, Germany). Aqueous $\mathrm{HCl}$ solution $(0.1 \mathrm{M}, 5 \mathrm{~mL})$ was passed through the generator and the eluate was collected in five $1 \mathrm{~mL}$ fractions. Aqueous NaOAc (1 M) was added to the fourth fraction $\left(1 \mathrm{~mL}\right.$, containing $~ 77.6 \mathrm{MBq}{ }^{68} \mathrm{Ga}$ ) to increase the $\mathrm{pH}$ to either $\mathrm{pH} 3.5$ or $\mathrm{pH}$ 6. Aliquots from the $\mathrm{pH}$ adjusted fraction were used for radiolabelling reactions. $\mathrm{H}_{2} \mathbf{L}$ was dissolved in DMSO $(1 \mathrm{mg} / \mathrm{mL})$ and diluted with ultrapure water. ${ }^{68} \mathrm{Ga}$ $(15 \mu \mathrm{L}, \sim 1.16 \mathrm{MBq}$ in $\mathrm{pH}$ adjusted solution) was added to chelator solutions $(105 \mu \mathrm{L})$ to provide solutions with chelator concentrations ranging from $0.5-500 \mu \mathrm{M}$ and the final reaction solution was incubated at $25^{\circ} \mathrm{C}, 40^{\circ} \mathrm{C}$ or $90^{\circ} \mathrm{C}$ for $10 \mathrm{~min}$. The reaction solutions were analysed via radio-HPLC (5-20 $\mu \mathrm{L}$ injection).

\subsection{Single-Crystal X-ray Diffraction Procedure}

Low-temperature (123 K or $173 \mathrm{~K}) \mathrm{X}$-ray intensity data were collected using a Rigaku XtaLAB Synergy diffractometer (Rigaku Oxford Diffraction, Chalgrove, Oxford, United Kingdom) fitted with a Hypix6000HE hybrid photon counting detector and MoK $\alpha$ $(\lambda=0.71073 \AA)$ or $\mathrm{CuK} \alpha(\lambda=1.54184 \AA)$ radiation. Data were processed, including a multiscan absorption correction, using the proprietary diffractometer software package CrysAlisPro v1.171.39.46 [93]. The structure was solved by conventional methods and refined on $F^{2}$ using full matrix least squares using the SHELX 2018/3 software suite [94]. Non-hydrogen atoms were refined with anisotropic displacement parameters. Hydrogen atoms attached to carbon were placed in calculated positions and were refined using a riding model. The positions of the acidic hydrogen atoms attached to nitrogen were initially located in the difference Fourier map but were included in calculated positions and refined using a riding model. In the $[\mathrm{CoHL}]\left(\mathrm{BPh}_{4}\right)$ and $[\mathrm{ZnHL}]\left(\mathrm{BPh}_{4}\right)$ complexes, solvent 
molecules were successfully modelled. However, after refinement of the primary molecule $[\mathrm{MnHL}]\left(\mathrm{BPh}_{4}\right)$, residual electron density was assumed to be isolated solvent molecules located in the crystal lattice. These were accounted for using PLATON/SQUEEZE [95]. CSD reference numbers 2072659-2072661.

\subsection{DFT Calculations}

Density functional theory (DFT) calculations were performed using the Gaussian 16 program package with the Becke, 3-parameter, Lee-Yang-Parr (B3LYP) functional and the DGDZVP basis set for the $\mathrm{Zn}^{2+}$ complexes [96-100]. The B3LYP functional and the standard Ahlrichs valence triple- $\xi$ including polarization functions (TZVP) basis set were used for the high-spin $\mathrm{Co}^{2+}$ complexes [101,102]. The geometries of the various complexes were fully optimised without imposing any symmetry constraint. No imaginary frequencies were found at the optimised molecular geometries, which indicate that they are real minima of the potential energy surface. The complexes were optimised in aqueous solution by using the polarizable continuum model with the integral equation formalism variant (IEFPCM), which creates a solvent cavity via a set of overlapping spheres [103]. The calculated relative energies of the complexes include nonpotential energy contributions. Calculation results were visualized and interpreted using GaussView version 6.1.1 [104].

\section{Conclusions}

Hybrid thiosemicarbazone ligands are of interest in the development of biologicallyactive metal complexes and radiopharmaceuticals. A variant of cyclen with two thiosemicarbazone pendant groups was synthesised and the coordination complexes with $\mathrm{Mn}^{2+}$, $\mathrm{Co}^{2+}$ and $\mathrm{Zn}^{2+}$ were prepared and characterised. ${ }^{1} \mathrm{H}$ NMR spectroscopy of $[\mathrm{ZnHL}]\left(\mathrm{BPh}_{4}\right)$ indicated the formation of a singly deprotonated ligand with one pendant arm coordinated to the metal centre. X-ray crystallography of [MnHL] $\left(\mathrm{BPh}_{4}\right)$ and $[\mathrm{ZnHL}]\left(\mathrm{BPh}_{4}\right)$ indicated the formation of the $\Delta(\delta, \delta, \delta, \delta) / \Lambda(\lambda, \lambda, \lambda, \lambda)$ and $\Delta(\lambda, \lambda, \lambda, \lambda) / \Lambda(\delta, \delta, \delta, \delta)$ diastereomers, whereas [CoHL] $\left(\mathrm{BPh}_{4}\right)$ was present as the $\Delta(\delta, \delta, \delta, \delta) / \Lambda(\lambda, \lambda, \lambda, \lambda)$ and $\Delta(\lambda, \lambda, \lambda, \delta) / \Lambda(\delta, \delta, \delta, \lambda)$ diastereomers. The distorted trigonal prismatic geometries of the high-spin $\mathrm{Mn}^{2+}, \mathrm{Co}^{2+}$ and $\mathrm{Zn}^{2+}$ complexes are a result of the steric constraints of the ligand. DFT calculations indicated small differences in the relative energies of the diastereomers, which suggests that they likely also exist in solution. Further studies are required to indicate whether the particular diastereomers could have distinct biological activities. Radiolabelling with ${ }^{68} \mathrm{Ga}^{3+}$ produced a single species at ligand concentrations between 50 and $500 \mu \mathrm{M}$ at $90{ }^{\circ} \mathrm{C}$ to achieve RCY $>95 \%$, indicating the potential of hybrid thiosemicarbazone ligands with radiometals in the development of radiopharmaceuticals. Investigations into additional metal ions and their properties are in progress.

Supplementary Materials: The following are available online: ${ }^{1} \mathrm{H}$ and ${ }^{13} \mathrm{C}\left\{{ }^{1} \mathrm{H}\right\}$ NMR spectra, ESI-MS spectra, HPLC spectra and computational methods.

Author Contributions: Conceptualization, B.M.P.; methodology, M.L.G., P.R.W.J.D. and B.M.P.; validation, M.L.G. and P.R.W.J.D.; formal analysis, M.L.G., P.R.W.J.D., C.M.F. and B.M.P.; investigation, M.L.G., P.R.W.J.D. and C.M.F.; resources, C.M.F. and B.M.P.; writing-original draft preparation, M.L.G., P.R.W.J.D. and B.M.P.; writing-review and editing, M.L.G., P.R.W.J.D., C.M.F. and B.M.P.; visualization, M.L.G. and P.R.W.J.D.; supervision, B.M.P.; project administration, M.L.G. and B.M.P.; funding acquisition, B.M.P. All authors have read and agreed to the published version of the manuscript.

Funding: This research was funded by the Australian Research Council, grant number DE170100540 and a National Imaging Facility Fellowship (B.M.P.). M.L.G. and P.R.W.J.D. were supported by the Australian Government with a Research Training Program Stipend.

Institutional Review Board Statement: Not applicable.

Informed Consent Statement: Not applicable.

Data Availability Statement: Data are available within the article or Supplementary Information. 
Acknowledgments: We gratefully acknowledge the facilities and scientific and technical assistance of the National Imaging Facility, a National Collaborative Research Infrastructure Strategy capability at Monash Biomedical Imaging, and the Monash Analytical Platform in the School of Chemistry, Monash University. We also thank S. R. Batten and K. S. Murray (School of Chemistry, Monash University) for the use of their laboratory facilities.

Conflicts of Interest: The authors declare no conflict of interest.

Sample Availability: Samples of compounds $\mathrm{H}_{2} \mathrm{~L},[\mathrm{MnHL}]\left(\mathrm{BPh}_{4}\right),[\mathrm{CoHL}]\left(\mathrm{BPh}_{4}\right)$ and $[\mathrm{ZnHL}]\left(\mathrm{BPh}_{4}\right)$ are available from the authors.

\section{References}

1. Richardson, D.; Kalinowski, D.S.; Richardson, V.; Sharpe, P.; Lovejoy, D.B.; Islam, M.; Bernhardt, P.V. 2-Acetylpyridine Thiosemicarbazones are Potent Iron Chelators and Antiproliferative Agents: Redox Activity, Iron Complexation and Characterization of their Antitumor Activity. J. Med. Chem. 2009, 52, 1459-1470. [CrossRef]

2. Pedrido, R.; González-Noya, A.M.; Romero, M.J.; Martínez-Calvo, M.; López, M.V.; Gómez-Fórneas, E.; Zaragoza, G.; Bermejo, M.R.; Verez, G.Z. Pentadentate thiosemicarbazones as versatile chelating systems. A comparative structural study of their metallic complexes. Dalton Trans. 2008, 6776-6787. [CrossRef] [PubMed]

3. Nomiya, K.; Sekino, K.; Ishikawa, M.; Honda, A.; Yokoyama, M.; Kasuga, N.C.; Yokoyama, H.; Nakano, S.; Onodera, K. Syntheses, crystal structures and antimicrobial activities of monomeric 8-coordinate, and dimeric and monomeric 7-coordinate bismuth(III) complexes with tridentate and pentadentate thiosemicarbazones and pentadentate semicarbazone ligands. J. Inorg. Biochem. 2004, 98, 601-615. [CrossRef] [PubMed]

4. Paterson, B.M.; White, J.M.; Donnelly, P.S. A hexadentate bis(thiosemicarbazonato) ligand: Rhenium(V), iron(III) and cobalt(III) complexes. Dalton Trans. 2010, 39, 2831-2837. [CrossRef] [PubMed]

5. Pavlishchuk, V.V.; Kolotilov, S.V.; Addison, A.W.; Butcher, R.J.; Sinn, E. Nickel(II) complexes with dithiadiiminoamine and dithiabis(thiosemicarbazone) ligands. J. Chem. Soc. Dalton Trans. 2000, 335-341. [CrossRef]

6. Zaltariov, M.F.; Hammerstad, M.; Arabshahi, H.J.; Jovanović, K.; Richter, K.W.; Cazacu, M.; Shova, S.; Balan, M.; Andersen, N.H.; Radulović, S.; et al. New Iminodiacetate-Thiosemicarbazone Hybrids and Their Copper(II) Complexes Are Potential Ribonucleotide Reductase R2 Inhibitors with High Antiproliferative Activity. Inorg. Chem. 2017, 56, 3532-3549. [CrossRef]

7. Paterson, B.M.; White, K.F.; White, J.M.; Abrahams, B.F.; Donnelly, P.S. Guest-induced Assembly of Bis(thiosemicarbazonato) Zinc(II) Coordination Nanotubes. Angew. Chem. Int. Ed. 2017, 56, 8370-8374. [CrossRef]

8. Dayal, D.; Palanimuthu, D.; Shinde, S.V.; Somasundaram, K.; Samuelson, A.G. A novel zinc bis(thiosemicarbazone) complex for live cell imaging. JBIC J. Biol. Inorg. Chem. 2011, 16, 621-632. [CrossRef]

9. Huseynova, M.; Medjidov, A.; Taslimi, P.; Aliyeva, M. Synthesis, characterization, crystal structure of the coordination polymer $\mathrm{Zn}(\mathrm{II})$ with thiosemicarbazone of glyoxalic acid and their inhibitory properties against some metabolic enzymes. Bioorg. Chem. 2019, 83, 55-62. [CrossRef]

10. Crouch, P.J.; Hung, L.W.; Adlard, P.A.; Cortes, M.; Lal, V.; Filiz, G.; Perez, K.A.; Nurjono, M.; Caragounis, A.; Du, T.; et al. Increasing $\mathrm{Cu}$ bioavailability inhibits A oligomers and tau phosphorylation. Proc. Natl. Acad. Sci. USA 2009, 106, 381-386. [CrossRef]

11. Oliveira, C.; Maia, P.I.D.S.; Souza, P.C.; Pavan, F.R.; Leite, C.Q.F.; Viana, R.B.; Batista, A.A.; Nascimento, O.R.; Deflon, V.M. Manganese(II) complexes with thiosemicarbazones as potential anti-Mycobacterium tuberculosis agents. J. Inorg. Biochem. 2014, 132, 21-29. [CrossRef] [PubMed]

12. Beraldo, H.; Gambino, D. The Wide Pharmacological Versatility of Semicarbazones, Thiosemicarbazones and Their Metal Complexes. Mini-Rev. Med. Chem. 2004, 4, 31-39. [CrossRef]

13. Paterson, B.; Donnelly, P.S. Copper complexes of bis(thiosemicarbazones): From chemotherapeutics to diagnostic and therapeutic radiopharmaceuticals. Chem. Soc. Rev. 2011, 40, 3005-3018. [CrossRef] [PubMed]

14. Dilworth, J.R.; Hueting, R. Metal complexes of thiosemicarbazones for imaging and therapy. Inorg. Chim. Acta 2012, 389, 3-15. [CrossRef]

15. Mendes, I.C.; Soares, M.A.; Dos Santos, R.G.; Pinheiro, C.; Beraldo, H. Gallium(III) complexes of 2-pyridineformamide thiosemicarbazones: Cytotoxic activity against malignant glioblastoma. Eur. J. Med. Chem. 2009, 44, 1870-1877. [CrossRef] [PubMed]

16. Li, M.X.; Chen, C.L.; Zhang, D.; Niu, J.Y.; Ji, B.S. Mn(II), Co(II) and Zn(II) complexes with heterocyclic substituted thiosemicarbazones: Synthesis, characterization, X-ray crystal structures and antitumor comparison. Eur. J. Med. Chem. 2010, 45, 3169-3177. [CrossRef]

17. Yu, Y.; Kalinowski, D.S.; Kovacevic, Z.; Siafakas, A.R.; Jansson, P.J.; Stefani, C.; Lovejoy, D.B.; Sharpe, P.; Bernhardt, P.V.; Richardson, D.R. Thiosemicarbazones from the Old to New: Iron Chelators That Are More Than Just Ribonucleotide Reductase Inhibitors. J. Med. Chem. 2009, 52, 5271-5294. [CrossRef]

18. Li, M.-X.; Zhang, D.; Zhang, L.-Z.; Niu, J.-Y.; Ji, B.-S. Synthesis, crystal structures and biological activities of 2-acetylpyridine $\mathrm{N}(4)$-cyclohexylthiosemicarbazone and its manganese(II) and nickel(II) complexes. Inorg. Chem. Commun. 2010, 13, 1572-1575. [CrossRef] 
19. Bernhardt, P.V.; Sharpe, P.C.; Islam, M.; Lovejoy, D.B.; Kalinowski, D.S.; Richardson, D.R. Iron Chelators of the Dipyridylketone Thiosemicarbazone Class: Precomplexation and Transmetalation Effects on Anticancer Activity. J. Med. Chem. 2009, 52, 407-415. [CrossRef]

20. Stacy, A.E.; Palanimuthu, D.; Bernhardt, P.V.; Kalinowski, D.S.; Jansson, P.J.; Richardson, D.R. Zinc(II)-Thiosemicarbazone Complexes Are Localized to the Lysosomal Compartment Where They Transmetallate with Copper Ions to Induce Cytotoxicity. J. Med. Chem. 2016, 59, 4965-4984. [CrossRef]

21. Arion, V.B.; Jakupec, M.; Galanski, M.; Unfried, P.; Keppler, B.K. Synthesis, structure, spectroscopic and in vitro antitumour studies of a novel gallium(III) complex with 2-acetylpyridine 4N-dimethylthiosemicarbazone. J. Inorg. Biochem. 2002, 91, 298-305. [CrossRef]

22. Kowol, C.R.; Berger, R.; Eichinger, R.; Roller, A.; Jakupec, M.; Schmidt, P.P.; Arion, V.B.; Keppler, B.K. Gallium(III) and Iron(III) Complexes of $\alpha-\mathrm{N}-$ Heterocyclic Thiosemicarbazones: Synthesis, Characterization, Cytotoxicity, and Interaction with Ribonucleotide Reductase. J. Med. Chem. 2007, 50, 1254-1265. [CrossRef] [PubMed]

23. Qi, J.; Deng, J.; Qian, K.; Tian, L.; Li, J.; He, K.; Huang, X.; Cheng, Z.; Zheng, Y.; Wang, Y. Novel 2-pyridinecarboxaldehyde thiosemicarbazones $\mathrm{Ga}(\mathrm{III})$ complexes with a high antiproliferative activity by promoting apoptosis and inhibiting cell cycle. Eur. J. Med. Chem. 2017, 134, 34-42. [CrossRef] [PubMed]

24. Qi, J.; Qian, K.; Tian, L.; Cheng, Z.; Wang, Y. Gallium(III)-2-benzoylpyridine-thiosemicarbazone complexes promote apoptosis through $\mathrm{Ca}^{2+}$ signaling and ROS-mediated mitochondrial pathways. New J. Chem. 2018, 42, 10226-10233. [CrossRef]

25. King, A.P.; Gellineau, H.A.; Ahn, J.-E.; MacMillan, S.N.; Wilson, J.J. Bis(thiosemicarbazone) Complexes of Cobalt(III). Synthesis, Characterization, and Anticancer Potential. Inorg. Chem. 2017, 56, 6609-6623. [CrossRef]

26. West, D.X.; Nassar, A.; El-Saied, F.A.; Ayad, M.I. Cobalt(II) complexes with 2-aminoacetophenone N(4)-substituted thiosemicarbazones. Transit. Met. Chem. 1999, 24, 617-621. [CrossRef]

27. Deng, J.; Li, T.; Su, G.; Qin, Q.-P.; Liu, Y.; Gou, Y. Co(III) complexes based on $\alpha$-N-heterocyclic thiosemicarbazone ligands: DNA binding, DNA cleavage, and topoisomerase I/II inhibitory activity studies. J. Mol. Struct. 2018, 1167, 33-43. [CrossRef]

28. Di Vaira, M.; Bazzicalupi, C.; Orioli, P.; Messori, L.; Bruni, A.B.; Zatta, P. Clioquinol, a Drug for Alzheimer's Disease Specifically Interfering with Brain Metal Metabolism: Structural Characterization of Its Zinc(II) and Copper(II) Complexes. Inorg. Chem. 2004, 43, 3795-3797. [CrossRef] [PubMed]

29. Yoshikawa, Y.; Yasui, H. Zinc complexes developed as metallopharmaceutics for treating diabetes mellitus based on the biomedicinal inorganic chemistry. Curr. Top. Med. Chem. 2012, 12, 210-218. [CrossRef]

30. Chukwuma, C.I.; Mashele, S.S.; Eze, K.C.; Matowane, G.R.; Islam, S.M.; Bonnet, S.L.; Noreljaleel, A.E.; Ramorobi, L.M. A comprehensive review on zinc(II) complexes as anti-diabetic agents: The advances, scientific gaps and prospects. Pharmacol. Res. 2020, 155, 104744. [CrossRef]

31. Liu, Y.-C.; Wei, J.-H.; Chen, Z.-F.; Liu, M.; Gu, Y.-Q.; Huang, K.-B.; Li, Z.-Q.; Liang, H. The antitumor activity of zinc(II) and copper(II) complexes with 5,7-dihalo-substituted-8-quinolinoline. Eur. J. Med. Chem. 2013, 69, 554-563. [CrossRef] [PubMed]

32. Zhang, Y.; Li, X.; Li, J.; Khan, Z.H.; Ma, F.; Liu, X. A novel zinc complex with antibacterial and antioxidant activity. BMC Chem. 2021, 15, 1-12. [CrossRef] [PubMed]

33. Kasuga, N.C.; Sekino, K.; Ishikawa, M.; Honda, A.; Yokoyama, M.; Nakano, S.; Shimada, N.; Koumo, C.; Nomiya, K. Synthesis, structural characterization and antimicrobial activities of 12 zinc(II) complexes with four thiosemicarbazone and two semicarbazone ligands. J. Inorg. Biochem. 2003, 96, 298-310. [CrossRef]

34. Tarushi, A.; Totta, X.; Raptopoulou, C.; Psycharis, V.; Psomas, G.; Kessissoglou, D.P. Structural features of mono- and tri-nuclear $\mathrm{Zn}(\mathrm{II})$ complexes with a non-steroidal anti-inflammatory drug as ligand. Dalton Trans. 2012, 41, 7082. [CrossRef] [PubMed]

35. Fujibayashi, Y.; Taniuchi, H.; Yonekura, Y.; Ohtani, H.; Konishi, J.; Yokoyama, A. Copper-62-ATSM: A new hypoxia imaging agent with high membrane permeability and low redox potential. J. Nucl. Med. 1997, 38, 1155-1160.

36. Torres, J.B.; Andreozzi, E.M.; Dunn, J.T.; Siddique, M.; Szanda, I.; Howlett, D.R.; Sunassee, K.; Blowera, P.J.; Torres, J.B. PET Imaging of Copper Trafficking in a Mouse Model of Alzheimer Disease. J. Nucl. Med. 2015, 57, 109-114. [CrossRef]

37. Andreozzi, E.M.; Torres, J.B.; Sunassee, K.; Dunn, J.; Walker-Samuel, S.; Szanda, I.; Blower, P.J. Studies of copper trafficking in a mouse model of Alzheimer's disease by positron emission tomography: Comparison of ${ }^{64} \mathrm{Cu}$ acetate and ${ }^{64} \mathrm{CuGTSM}$. Metallomics 2017, 9, 1622-1633. [CrossRef]

38. Paterson, B.M.; Cullinane, C.; Crouch, P.J.; White, A.R.; Barnham, K.J.; Roselt, P.D.; Noonan, W.; Binns, D.; Hicks, R.J.; Donnelly, P.S. Modification of Biodistribution and Brain Uptake of Copper Bis(thiosemicarbazonato) Complexes by the Incorporation of Amine and Polyamine Functional Groups. Inorg. Chem. 2019, 58, 4540-4552. [CrossRef]

39. Hickey, J.L.; Lim, S.; Hayne, D.; Paterson, B.; White, J.M.; Villemagne, V.L.; Roselt, P.; Binns, D.; Cullinane, C.; Jeffery, C.M.; et al. Diagnostic Imaging Agents for Alzheimer's Disease: Copper Radiopharmaceuticals that Target A $\beta$ Plaques. J. Am. Chem. Soc. 2013, 135, 16120-16132. [CrossRef]

40. McInnes, L.E.; Noor, A.; Kysenius, K.; Cullinane, C.; Roselt, P.; McLean, C.A.; Chiu, F.C.K.; Powell, A.K.; Crouch, P.J.; White, J.M.; et al. Potential Diagnostic Imaging of Alzheimer's Disease with Copper-64 Complexes That Bind to Amyloid- $\beta$ Plaques. Inorg. Chem. 2019, 58, 3382-3395. [CrossRef]

41. Cowley, A.R.; Dilworth, J.R.; Donnelly, P.S.; Heslop, J.M.; Ratcliffe, S.J. Bifunctional chelators for copper radiopharmaceuticals: The synthesis of [Cu(ATSM)-amino acid] and [Cu(ATSM)-octreotide] conjugates. Dalton Trans. 2007, 209-217. [CrossRef] [PubMed] 
42. Paterson, B.; Karas, J.A.; Scanlon, D.B.; White, J.M.; Donnelly, P.S. Versatile New Bis(thiosemicarbazone) Bifunctional Chelators: Synthesis, Conjugation to Bombesin(7-14)-NH2, and Copper-64 Radiolabeling. Inorg. Chem. 2010, 49, 1884-1893. [CrossRef]

43. Hueting, R.; Christlieb, M.; Dilworth, J.R.; Garayoa, E.G.; Gouverneur, V.; Jones, M.W.; Maes, V.; Schibli, R.; Sun, X.; Tourwé, D.A. Bis(thiosemicarbazones) as bifunctional chelators for the room temperature 64-copper labeling of peptides. Dalton Trans. 2010, 39, 3620-3632. [CrossRef] [PubMed]

44. Rösch, F. Past, present and future of ${ }^{68} \mathrm{Ge} /{ }^{68} \mathrm{Ga}$ generators. Appl. Radiat. Isot. 2013, 76, 24-30. [CrossRef] [PubMed]

45. Mjos, K.D.; Orvig, C. Metallodrugs in Medicinal Inorganic Chemistry. Chem. Rev. 2014, 114, 4540-4563. [CrossRef] [PubMed]

46. Ramogida, C.F.; Orvig, C. Tumour targeting with radiometals for diagnosis and therapy. Chem. Commun. 2013, 49, 4720-4739. [CrossRef] [PubMed]

47. Hennrich, U.; Benešová, M. $\left[{ }^{68} \mathrm{Ga}\right]$ Ga-DOTA-TOC: The First FDA-Approved ${ }^{68}$ Ga-Radiopharmaceutical for PET Imaging. Pharmaceuticals 2020, 13, 38. [CrossRef] [PubMed]

48. Eder, M.; Neels, O.; Müller, M.; Bauder-Wüst, U.; Remde, Y.; Schafer, M.A.; Hennrich, U.; Eisenhut, M.; Afshar-Oromieh, A.; Haberkorn, U.; et al. Novel Preclinical and Radiopharmaceutical Aspects of [68Ga]Ga-PSMA-HBED-CC: A New PET Tracer for Imaging of Prostate Cancer. Pharmaceuticals 2014, 7, 779-796. [CrossRef]

49. Tsionou, M.I.; Knapp, C.E.; Foley, C.A.; Munteanu, C.R.; Cakebread, A.; Imberti, C.; Eykyn, T.R.; Young, J.D.; Paterson, B.M.; Blower, P.J.; et al. Comparison of macrocyclic and acyclic chelators for gallium-68 radiolabelling. RSC Adv. 2017, 7, 49586-49599. [CrossRef] [PubMed]

50. Sinnes, J.-P.; Nagel, J.; Waldron, B.P.; Maina, T.; Nock, B.A.; Bergmann, R.K.; Ullrich, M.; Pietzsch, J.; Bachmann, M.; Baum, R.P.; et al. Instant kit preparation of ${ }^{68}$ Ga-radiopharmaceuticals via the hybrid chelator DATA: Clinical translation of $\left[{ }^{68} \mathrm{Ga}\right]$ Ga-DATA-TOC. EJNMMI Res. 2019, 9, 48. [CrossRef]

51. Joshi, T.; Graham, B.; Spiccia, L. Macrocyclic Metal Complexes for Metalloenzyme Mimicry and Sensor Development. Accounts Chem. Res. 2015, 48, 2366-2379. [CrossRef]

52. Lejault, P.; Duskova, K.; Bernhard, C.; Valverde, I.E.; Romieu, A.; Monchaud, D. The Scope of Application of Macrocyclic Polyamines Beyond Metal Chelation. Eur. J. Org. Chem. 2019, 2019, 6146-6157. [CrossRef]

53. Shinoda, S. Dynamic cyclen-metal complexes for molecular sensing and chirality signaling. Chem. Soc. Rev. 2013, 42, 1825-1835. [CrossRef]

54. Rashid, H.U.; Martines, M.A.U.; Jorge, J.; De Moraes, P.M.; Umar, M.N.; Khan, K.; Rehman, H.U. Cyclen-based Gd ${ }^{3+}$ complexes as MRI contrast agents: Relaxivity enhancement and ligand design. Bioorg. Med. Chem. 2016, 24, 5663-5684. [CrossRef] [PubMed]

55. Cabbiness, D.K.; Margerum, D.W. Macrocyclic effect on the stability of copper(II) tetramine complexes. J. Am. Chem. Soc. 1969, 91, 6540-6541. [CrossRef]

56. Hancock, R.D.; Martell, A.E. The Chelate, Cryptate and Macrocyclic Effects. Comments Inorg. Chem. 1988, 6, 237-284. [CrossRef]

57. Baranyai, Z.; Tircsó, G.; Rösch, F. The Use of the Macrocyclic Chelator DOTA in Radiochemical Separations. Eur. J. Inorg. Chem. 2020, 2020, 36-56. [CrossRef]

58. Stasiuk, G.; Long, N.J. The ubiquitous DOTA and its derivatives: The impact of 1,4,7,10-tetraazacyclododecane-1,4,7,10-tetraacetic acid on biomedical imaging. Chem. Commun. 2013, 49, 2732-2746. [CrossRef] [PubMed]

59. Burke, B.P.; Clemente, G.S.; Archibald, S.J. Recent advances in chelator design and labelling methodology for ${ }^{68}$ Ga radiopharmaceuticals. J. Label. Compd. Radiopharm. 2014, 57, 239-243. [CrossRef] [PubMed]

60. Molnár, E.; Camus, N.; Patinec, V.; Rolla, G.A.; Botta, M.; Tircsó, G.; Kálmán, F.K.; Fodor, T.; Tripier, R.; Platas-Iglesias, C. Picolinate-Containing Macrocyclic $\mathrm{Mn}^{2+}$ Complexes as Potential MRI Contrast Agents. Inorg. Chem. 2014, 53, 5136-5149. [CrossRef] [PubMed]

61. Pfeifer, A.; Knigge, U.; Mortensen, J.; Oturai, P.; Berthelsen, A.K.; Loft, A.; Binderup, T.; Rasmussen, P.; Elema, D.; Klausen, T.L.; et al. Clinical PET of Neuroendocrine Tumors Using 64Cu-DOTATATE: First-in-Humans Study. J. Nucl. Med. 2012, 53, 1207-1215. [CrossRef]

62. Demirci, E.; Kabasakal, L.; Toklu, T.; Ocak, M.; Şahin, O.E.; Alan-Selcuk, N.; Araman, A. 177Lu-DOTATATE therapy in patients with neuroendocrine tumours including high-grade (WHO G3) neuroendocrine tumours: Response to treatment and long-term survival update. Nucl. Med. Commun. 2018, 39, 789-796. [CrossRef] [PubMed]

63. Lange, J.L.; Davey, P.R.W.J.; Ma, M.T.; White, J.M.; Morgenstern, A.; Bruchertseifer, F.; Blower, P.J.; Paterson, B.M. An octadentate bis(semicarbazone) macrocycle: A potential chelator for lead and bismuth radiopharmaceuticals. Dalton Trans. 2020, 49, 14962-14974. [CrossRef] [PubMed]

64. Alam, I.S.; Arrowsmith, R.L.; Cortezon-Tamarit, F.; Twyman, F.; Kociok-Köhn, G.; Botchway, S.W.; Dilworth, J.R.; Carroll, L.; Aboagye, E.O.; Pascu, S.I. Microwave gallium-68 radiochemistry for kinetically stable bis(thiosemicarbazone) complexes: Structural investigations and cellular uptake under hypoxia. Dalton Trans. 2015, 45, 144-155. [CrossRef]

65. Arrowsmith, R.L.; Waghorn, P.A.; Jones, M.W.; Bauman, A.; Brayshaw, S.K.; Hu, Z.; Kociok-Kohn, G.D.; Mindt, T.L.; Tyrrell, R.M.; Botchway, S.W.; et al. Fluorescent gallium and indium bis(thiosemicarbazonates) and their radiolabelled analogues: Synthesis, structures and cellular confocal fluorescence imaging investigations. Dalton Trans. 2011, 40, 6238-6252. [CrossRef]

66. Jalilian, A.R.; Mehdipour, P.; Akhlaghi, M.; Yousefnia, H.; Shafaii, K. Evaluation of a [67Ga]-Thiosemicarbazone Complex as Tumor Imaging Agent. Sci. Pharm. 2009, 77, 343-354. [CrossRef] 
67. Moghadam, F.H.; Jalilian, A.R.; Nemati, A.; Abedini, M. Preparation and biodistribution studies of $\left[{ }^{67}\right.$ Ga $] 2$-acetylpyridine 4,4-dimethyl thiosemicarbazone complex as a possible SPECT tracer for detection of malignancies. J. Radioanal. Nucl. Chem. 2007, 272, 115-121. [CrossRef]

68. Lima, L.; Beyler, M.; Delgado, R.; Platas-Iglesias, C.; Tripier, R. Investigating the Complexation of the $\mathrm{Pb}^{2+} / \mathrm{Bi}^{3+} \mathrm{Pair}$ with Dipicolinate Cyclen Ligands. Inorg. Chem. 2015, 54, 7045-7057. [CrossRef]

69. Corey, E.J.; Bailar, J.C., Jr. The Stereochemistry of Complex Inorganic Compounds. XXII. Stereospecific Effects in Complex Ions. J. Am. Chem. Soc. 1959, 81, 2620-2629. [CrossRef]

70. Eisenberg, R.; Brennessel, W.W. Redetermination of the trigonal prismatic complex tris(cis-1,2-diphenylethylene-1,2dithiolato)rhenium. Acta Crystallogr. Sect. C Cryst. Struct. Commun. 2006, 62, 464-466. [CrossRef]

71. Tsuboyama, S.; Matsudo, M.; Tsuboyama, K.; Sakurai, T. Structures of [(R)- and (S)-prolinato](optically active cyclen)cobalt(III) complexes. Acta Crystallogr. Sect. C Cryst. Struct. Commun. 1989, 45, 872-876. [CrossRef]

72. Danker, F.; Näther, C.; Bensch, W. Synthesis and crystal structure of $\left(1,4,7,10\right.$-tetraazacyclododecane- $\left.\kappa^{4} N\right)\left(\right.$ tetrasulfido-- $\left.{ }^{2} S^{1}, S^{4}\right)$ manganese(II). Acta Crystallogr. Sect. E Crystallogr. Commun. 2020, 76, 456-460. [CrossRef] [PubMed]

73. Vargová, Z.; Kotek, J.; Rudovsky, J.; Plutnar, J.; Gyepes, R.; Hermann, P.; Györyová, K.; Lukeš, I. Ternary Complexes of Zinc(II), Cyclen and Pyridinecarboxylic Acids. Eur. J. Inorg. Chem. 2007, 2007, 3974-3987. [CrossRef]

74. Martinelli, J.; Balali-Mood, B.; Panizzo, R.; Lythgoe, M.F.; White, A.J.P.; Ferretti, P.; Steinke, J.H.G.; Vilar, R. Coordination chemistry of amide-functionalised tetraazamacrocycles: Structural, relaxometric and cytotoxicity studies. Dalton Trans. 2010, 39 , 10056-10067. [CrossRef]

75. El Safadi, M.; Bhadbhade, M.; Shimmon, R.; Baker, A.T.; McDonagh, A.M. Cyclen-based chelators for the inhibition of A $\beta$ aggregation: Synthesis, anti-oxidant and aggregation evaluation. Inorg. Chim. Acta 2017, 467, 343-350. [CrossRef]

76. Bernier, N.; Costa, J.; Delgado, R.; Félix, V.; Royal, G.; Tripier, R. trans-Methylpyridine cyclen versus cross-bridged transmethylpyridine cyclen. Synthesis, acid-base and metal complexation studies (metal $=\mathrm{Co}^{2+}, \mathrm{Cu}^{2+}$, and $\mathrm{Zn}^{2+}$ ). Dalton Trans. 2011, 40, 4514-4526. [CrossRef]

77. Tsitovich, P.B.; Tittiris, T.Y.; Cox, J.M.; Benedict, J.B.; Morrow, J.R. Fe(II) and Co(II) N-methylated CYCLEN complexes as paraSHIFT agents with large temperature dependent shifts. Dalton Trans. 2017, 47, 916-924. [CrossRef]

78. Knight, J.C.; Alvarez, S.; Angelo, J.A.; Edwards, P.G.; Singh, N. A novel bipyridine-based hexadentate tripodal framework with a strong preference for trigonal prismatic co-ordination geometries. Dalton Trans. 2010, 39, 3870-3883. [CrossRef]

79. Aoki, S.; Zulkefeli, M.; Shiro, M.; Kimura, E. New supramolecular trigonal prisms from zinc(II)-1,4,7,10-tetraazacyclododecane (cyclen) complexes and trithiocyanurate in aqueous solution. Proc. Natl. Acad. Sci. USA 2002, 99, 4894-4899. [CrossRef]

80. Kojima, M.; Nakabayashi, K.; Ohba, S.; Okumoto, S.; Saito, Y.; Fujita, J. Green and Brown Isomers of the ((S)-1-Amino-2propanethiolato-N,S)(1,4,7,10-tetraazacyclododecane)cobalt(III) Ion and Crystal Structure of the Green Isomer. Bull. Chem. Soc. Jpn. 1986, 59, 277-283. [CrossRef]

81. Chandra, S. and Sangeetika. Synthesis and spectral studies on copper(II) and cobalt(II) complexes of macrocyclic ligand containing thiosemicarbazone moiety. Ind. J. Chem. A 2002, 41, 1629.

82. Chandra, S.; Pundir, M. Spectral studies of cobalt(II) complexes of 12-membered macrocyclic ligands having thiosemicarbazone moieties. Spectrochim. Acta Part A Mol. Biomol. Spectrosc. 2007, 68, 883-890. [CrossRef] [PubMed]

83. Tsitovich, P.B.; Morrow, J.R. Macrocyclic ligands for Fe(II) paraCEST and chemical shift MRI contrast agents. Inorg. Chim. Acta 2012, 393, 3-11. [CrossRef]

84. Howard, J.A.K.; Kenwright, A.; Moloney, J.M.; Parker, D.; Woods, M.; Port, M.; Navet, M.; Rousseau, O. Structure and dynamics of all of the stereoisomers of europium complexes of tetra(carboxyethyl) derivatives of dota: Ring inversion is decoupled from cooperative arm rotation in the RRRR and RRRS isomers. Chem. Commun. 1998, 1381-1382. [CrossRef]

85. Enamullah, M.; Vasylyeva, V.; Janiak, C. Chirality and diastereoselection of $\Delta / \Lambda$-configured tetrahedral zinc(II) complexes with enantiopure or racemic Schiff base ligands. Inorg. Chim. Acta 2013, 408, 109-119. [CrossRef]

86. Chamayou, A.-C.; Lüdeke, S.; Brecht, V.; Freedman, T.B.; Nafie, L.A.; Janiak, C. Chirality and Diastereoselection of $\Delta / \Lambda$ Configured Tetrahedral Zinc Complexes through Enantiopure Schiff Base Complexes: Combined Vibrational Circular Dichroism, Density Functional Theory, ${ }^{1} \mathrm{H}$ NMR, and X-ray Structural Studies. Inorg. Chem. 2011, 50, 11363-11374. [CrossRef] [PubMed]

87. Pescitelli, G.; Lüdeke, S.; Chamayou, A.-C.; Marolt, M.; Justus, V.; Górecki, M.; Arrico, L.; Di Bari, L.; Islam, M.A.; Gruber, I.; et al. Broad-Range Spectral Analysis for Chiral Metal Coordination Compounds: (Chiro)optical Superspectrum of Cobalt(II) Complexes. Inorg. Chem. 2018, 57, 13397-13408. [CrossRef]

88. Vargas, A.; Zerara, M.; Krausz, E.; Hauser, A.; Daku, L.M.L. Density-Functional Theory Investigation of the Geometric, Energetic, and Optical Properties of the Cobalt(II)tris(2,2'-bipyridine) Complex in the High-Spin and the Jahn-Teller Active Low-Spin States. J. Chem. Theory Comput. 2006, 2, 1342-1359. [CrossRef]

89. Wadas, T.; Wong, E.H.; Weisman, G.R.; Anderson, C.J. Coordinating Radiometals of Copper, Gallium, Indium, Yttrium, and Zirconium for PET and SPECT Imaging of Disease. Chem. Rev. 2010, 110, 2858-2902. [CrossRef]

90. Prado, V.D.S.; Leitao, R.C.F.; Silva, F.; Gano, L.; Santos, I.C.; Marques, F.L.N.; Paulo, A.R.; Deflon, V.M. Gallium and indium complexes with new hexadentate bis(semicarbazone) and bis(thiosemicarbazone) chelators. Dalton Trans. 2021, 50, 1631-1640. [CrossRef]

91. Earnshaw, A. Introduction to Magnetochemistry; Elsevier: London, UK, 1968.

92. Kahn, O. Molecular Magnetism; Wiley-VCH: New York, NY, USA, 1993. 
93. CrysAlisPro; Rigaku Oxford Diffraction: Yarnton, UK, 2018.

94. Sheldrick, G. Crystal Structure refinement with SHELXL. Acta Cryst. A 2015, 71, 3-8. [CrossRef] [PubMed]

95. Spek, A.A. PLATON SQUEEZE: A tool for the calculation of the disordered solvent contribution to the calculated structure factors. Acta Cryst. C 2015, 71, 9-18. [CrossRef] [PubMed]

96. Frisch, M.J.; Trucks, G.W.; Schlegel, H.B.; Scuseria, G.E.; Robb, M.A.; Cheeseman, J.R.; Scalmani, G.; Barone, V.; Petersson, G.A.; Nakatsuji, H.; et al. Gaussian 16 Rev. C.01; Gaussian, Inc.: Wallingford, CT, USA, 2016.

97. Becke, A.D. Density-functional thermochemistry. III. The role of exact exchange. J. Chem. Phys. 1993, 98, 5648-5652. [CrossRef]

98. Stephens, P.J.; Devlin, F.J.; Chabalowski, C.F.; Frisch, M.J. Ab Initio Calculation of Vibrational Absorption and Circular Dichroism Spectra Using Density Functional Force Fields. J. Phys. Chem. 1994, 98, 11623-11627. [CrossRef]

99. Godbout, N.; Salahub, D.R.; Andzelm, J.; Wimmer, E. Optimization of Gaussian-type basis sets for local spin density functional calculations. Part I. Boron through neon, optimization technique and validation. Can. J. Chem. 1992, 70, 560-571. [CrossRef]

100. Sosa, C.; Andzelm, J.; Elkin, B.C.; Wimmer, E.; Dobbs, K.D.; Dixon, D.A. A local density functional study of the structure and vibrational frequencies of molecular transition-metal compounds. J. Phys. Chem. 1992, 96, 6630-6636. [CrossRef]

101. Schäfer, A.; Horn, H.; Ahlrichs, R. Fully optimized contracted Gaussian basis sets for atoms Li to Kr. J. Chem. Phys. 1992, 97, 2571-2577. [CrossRef]

102. Schäfer, A.; Huber, C.; Ahlrichs, R. Fully optimized contracted Gaussian basis sets of triple zeta valence quality for atoms Li to Kr. J. Chem. Phys. 1994, 100, 5829-5835. [CrossRef]

103. Tomasi, J.; Mennucci, B.; Cammi, R. Quantum Mechanical Continuum Solvation Models. Chem. Rev. 2005, 105, $2999-3094$. [CrossRef] [PubMed]

104. Dennington, T.A.K.R.; Millam, J.M. GaussView; Version 6.1.1; Semichem Inc.: Shawnee Mission, KS, USA, 2016. 